\title{
Regional Labor Market Differences in Brazil and Search Frictions: Some Structural Estimates ${ }^{*}$
}

\author{
Paulo Felipe de Oliveira, ${ }^{\dagger}$ José Raimundo Carvalho ${ }^{\ddagger}$
}

\author{
Contents: 1. Introduction; 2. Regional Differences in Brazilian Labor Markets; 3. Empirical \\ Implementation of Job Search Models; 4. Empirical Analysis; 5. Results; 6. Concluding Remarks. \\ Keywords: Search Theory, Regional Differences, Structural Econometrics. \\ JEL Code: J64, C14, C41.
}

We estimate an equilibrium job search model for six metropolitan areas located in different regions of Brazil. Two mechanisms of wage determination are considered: wage posting by monopsony firms and Nash bilateral bargaining. In order to estimate the model, we use the non-parametric method developed by Bontemps, Robin, \& van den Berg [2000. Equilibrium search with continuous productivity dispersion: Theory and nonparametric estimation. International Economic Review, 41(2), 305-358]. There is significant heterogeneity among the estimated structural parameters for these regions. We succeed in rationalizing some well-known regional differences in wages, unemployment rates and productivity prevalent in Brazilian labor markets, thus offering new interpretations. Metropolitan regions in the Northeast have much lower $\lambda_{0}$ (arrival rate of wage offers for unemployed workers) and $\lambda_{1}$ (arrival rate of wage offers for employed workers) vis a vis areas in the South or Southeast regions. This is a new, and much more precise, result worth considering on the regional inequality debate in Brazil. Regional inequality in wages, besides being an outcome of its regional human capital distribution, can be rationalized as inequality of search frictions brought by differences in $\lambda_{1}$. We found a key (indirect) role for search frictions when analysing productivity differences as well. Since search frictions impact simultaneously on monopsony power as well as on productivity, in order to understand better regional productivity differences we must deepen our analysis on how these structural parameters are differentiated by regions. Labor market frictions add important insights into the regional debate, something not captured by more traditional econometric reduced form approaches.

\footnotetext{
"This paper has been circulating under the title "Estimation of an Equilibrium Search Model with Productivity Dispersion: a Regional Analysis for Brazil". We thank participants from the $33^{\text {rd }}$ Meeting of the Brazilian Econometric Society, 2011, and the $6^{\text {th }}$ CAEN-EPGE Meeting of Public Policy and Economic Growth, 2013, for valuable comments and suggestions. The usual disclaimer applies.

${ }^{\dagger}$ Ministério do Desenvolvimento, Indústria e Comércio Exterior. I would like to thank CNPq, Brazil.

${ }^{\ddagger}$ CAEN/UFC and LECO/CAEN/UFC. E-mail: josecarv@uf c.br
} 
Estimamos um modelo de procura de emprego de equilíbrio para seis regiões metropolitanas localizadas em diferentes regiões do Brasil. Dois mecanismos de determinação dos salários são considerados: postagem de salários por empresas monopsônicas e negociação bilateral a la Nash. Para estimar o modelo, usamos o método não-paramétrico desenvolvido por Bontemps, Robin, \& van den Berg [2000. Equilibrium search with continuous productivity dispersion: Theory and nonparametric estimation. International Economic Review, 41(2), 305-358]. Existe heterogeneidade significativa entre os parâmetros estruturais estimados para essas regiões. Conseguimos racionalizar diferenças regionais já bem conhecidas nos salários, taxas de desemprego e produtividade prevalentes nos mercados de trabalho brasileiros, oferecendo assim novas interpretações. Regiões metropolitanas do Nordeste possuem $\lambda_{0}$ (taxa de oferta de salários para trabalhadores empregados) e $\lambda_{1}$ (taxa de oferta de salários para trabalhadores empregados) muito menores vis a vis aquelas encontradas nas regiões Sul ou Sudeste. Este é um resultado novo e muito mais preciso que vale a pena ser considerado no debate regional da desigualdade no Brasil. A desigualdade regional nos salários, além de ser resultado da distribuição regional de capital humano, pode ser racionalizada através da desigualdade de friç̧ões trazidas por diferenças entre $\lambda_{1}$ 's. Evidenciamos também um papel (indireto) importante das friç̧ões de busca quando se analisam as diferenças de produtividade. Como os atritos de busca impactam simultaneamente sobre o poder de monopsônio, bem como sobre a produtividade, a fim de entender melhor as diferenças de produtividade regionais, devemos aprofundar nossa análise sobre como esses parâmetros estruturais são diferenciadas por regiões. Friç̧ões no mercado de trabalho adicionam importantes insights ao debate, algo que não é capturado por abordagens econométricas de forma "reduzidas" mais tradicionais.

\section{INTRODUCTION}

Job search theory considers the labor market an environment of imperfect information. This implies that transactions in this market need time and other resources to be held, since agents are not fully informed about the opportunities and characteristics which are relevant to the transaction (see Eckstein \& van den Berg, 2007 and Rogerson, Shimer, \& Wright, 2005). Hence, these models serve as a substitute for the analysis of labor markets outside the neoclassical paradigm of labor supply, which precludes the possibility of involuntary unemployment.

In an environment of imperfect information, firms can exploit the fact that workers are not fully informed about all opportunities and thus offer wages which are lower than the value of labor productivity, even in a situation where firms and workers are homogeneous (Burdett \& Mortensen, 1998). Thus, the prevailing wage may be smaller than in an environment of perfect competition, where wages would be equal to the marginal labor productivity. Moreover, from a structural estimation perspective, it is possible to analyze jointly, in a context of market equilibrium, labor market issues such as arrival rates of job offers for employed and unemployed workers, the separation rate of employment relations, firm's productivity, and monopsony power. Hence, one can make an attempt to infer the factors that would account for differences in unemployment rates between regions or would influence the level of frictions present in the labor market on wages, for example.

In this paper, parameters of an equilibrium job search model are estimated, where firms may differ in terms of labor productivity, based on six metropolitan areas located in different regions of Brazil. These metropolitan regions serve as a benchmark to analyse regional labor market differences. Although the methodology employed is not new, we believe our main contribution is to show the feasibility of analysing regional labor market differences by means of a structural model. In fact, our results are in 
accordance with stylized facts about regional inequality of Brazilian markets (see Reis \& Barros, 1990, Savedoff, 1990, Savedoff, 1995, Azzoni \& Servo, 2002, Queiroz \& Golgher, 2008, and Freguglia \& MenezesFilho, 2012). It also present new insights and hints on why such inequalities might exist.

The productivity debate in Brazil is also object of our analysis. In order to do that we confront two possible wage determination mechanisms: wage posting ex ante by monopsonist firms that set wages unilaterally, based in Bontemps, Robin, \& van den Berg (2000), and Nash bilateral bargaining ex post, based in Mortensen (2003). The methodology used to estimate the model is the nonparametric method of Bontemps et al. (2000), which enables us to estimate the model without assuming any parametric probability distribution of firms' productivity. Our results show the superiority of the Nash bilateral bargaining model, both in terms of fit as well as in terms of replicating stylised facts about regional productivity differences.

Although empirical analysis based on structural estimation of search models are already quite developed internationally, ${ }^{1}$ in Brazil, the literature is virtually nonexistent, and Carvalho (2012) and Oliveira (2011) are rare examples of structural analysis of a search model using Brazilian data (Survey of Living Standards-PPV). However, our paper not only develops and estimates a search model but also suggests that this methodology can shed important insights into the debate over regional labor market differences.

The empirical analysis in this study confirms and shows significant differences between regions. Some regions have a higher expected unemployment duration, as the metropolitan areas of Salvador and Rio de Janeiro, where the expected completed durations of unemployment are equal to approximately eleven months, while for the metropolitan region of Belo Horizonte this term is near four months. In the metropolitan area of Recife, employed workers have a low transition rate to jobs that pay higher wages, while regions such as São Paulo and Porto Alegre have a relatively high mobility. Despite these results, our methodology shows its strength when we are able to rationalize some well-known regional differences in Brazilian labor markets by means of deep structural parameters. Clearly, the role of labor market frictions, internal labor market dynamics and market organization (monopsony level) add important insights into the debate.

In terms of productivities, depending on the type assumed in the wage determination, we arrive at different conclusions. The model with wage posting inferred high-productivity levels, a result also found by Mortensen (2003) and Shimer (2006), and the bilateral bargaining has more plausible and theoretically admissible values that do not violate any theoretical restriction. In the case of bargaining, the metropolitan region of São Paulo has the highest level of productivity and Recife has the lowest level. When compared to Recife, the distribution of firms' productivity in São Paulo is also more dispersed. We believe that our estimates have the potential to contribute to the long-standing debate about regional differences in Brazilian labor markets (see, among others, Reis \& Barros, 1990, Savedoff, 1990, Savedoff, 1995, Azzoni \& Servo, 2002, Queiroz \& Golgher, 2008, and Freguglia \& Menezes-Filho, 2012).

Besides this introductory section, the paper is organized as follows: Section 2 presents a brief description of the recent debate about regional differences in Brazilian labor markets, focusing on three main labor market outcomes: wages, unemployment rate and productivity. Section 3 reviews the theoretical and empirical literature on structural estimation of search models in the labor market. Section 4 addresses the empirical part of the paper and it is split into three subsections: Theoretical Background, Data Set and Structural Estimation. Section 5 presents and discusses the main structural estimates and, finally, section 6 draws some final considerations.

\section{REGIONAL DIFFERENCES IN BRAZILIAN LABOR MARKETS}

According to Azzoni \& Servo (2002), among others, Brazil has a high level of regional inequality and the prospects of any improvement from the present to the medium run are at best disappointing. Although

\footnotetext{
${ }^{1}$ See Eckstein \& van den Berg (2007) for a literature review.
} 
this regional inequality can be discussed from many perspectives, income inequality (more specifically labor income) is the subject of most scrutiny in the literature. Azzoni \& Servo assert that

The Northeast region of Brazil is home to $28 \%$ of the Brazilian population in 2000; it produced only $13 \%$ of the Brazilian GDP in 1998. The rich Southeast region represented 43\% of the total population and produced $58 \%$ of GDP. Per capita income in the Northeast was $54 \%$ below the national average while in the Southeast it was $36 \%$ above that level. The poorest state, Piaui, in the Northeast region, had a per capita income level 5.6 times lower than the richest state, Sao Paulo, in the Southeast region.

Hence, it is a well-established fact that Brazilian labor markets are very heterogenous.

A less developed argument is that, besides earnings differences, regional inequality in Brazilian labor markets can be found, at least indirectly, when one looks at other indexes such as unemployment rates, unemployment duration, productivity differences, among other economic variables. In fact, labor market differences in Brazil is by no means a recent trend. As a matter of fact, much of our regional disparities can be traced back to colonial times, where the North-South (more precisely, Northeast-Southeast) disparities started up, enlarging during the last decades of development (Araújo \& Lima, 2010). In that sense, we think that a brief literature review on regional differences in Brazilian labor markets that considers those aspects of heterogeneity as well as the recent path of regional inequality is important for a better understanding of our arguments.

In order to start understanding regional differences in Brazilian labor markets during the first decade of the 21st century, we need to understand the macroeconomic environment surrounding that period. The Brazilian economy started to recover from a period of stagnation during the 1980s and mid-1990s, initiating a period of modest growth from 1995 on. But it was only during the period from 2004 up to 2008 that we observe a real acceleration in its growth rate. Basically, this acceleration took place simultaneously with

[...] the influence from the growth conditions of the world economy and domestic demand driven by real increases in the minimum wage, the expansion of personal credit and higher volume of federal cash transfers resources, and the multiplier effects of export activity benefited from major expansion of foreign demand for industrial and agricultural commodities. (Araújo \& Lima, 2010)

The rest of this section discusses three aspects of regional labor market differences in Brazi: wages, unemployment rate and productivity.

\subsection{Wage Differences}

Although the debate about income inequality is well established among Brazilian scholars (see, among others, Barros \& Mendonça, 1995, Langoni, 2005, Barros, Foguel, \& Ulyssea, 2006), the debate about income inequality with an emphasis on regional differences on earnings has received much less attention. Few papers like Reis \& Barros (1990), Savedoff (1990), Savedoff (1995), Azzoni \& Servo (2002), Queiroz \& Golgher (2008), and Freguglia \& Menezes-Filho (2012) treat in an explicitly manner the stark earnings differences among Brazilian regions, pointing out the important role that human capital unequal distribution has on this inequality as well as other observed and unobserved individual heterogeneities. ${ }^{2}$ Table 1 shows the evolution of the average monthly earnings between regions in Brazil.

Table 1 and Figure 1 show clearly that the Southeast region was the leader in labor productivity until 2007 (only surpassed by the Center-West mainly due to agricultural productiviy) and the Northeast region remains at the last place. Also, the gap between Southeast and Northeast remains almost unchanged.

\footnotetext{
${ }^{2}$ However, some evidence point out to the fact that these differences are considerably reduced once we control for unobserved heterogeneity at the individual level, accordingly to Freguglia \& Menezes-Filho (2012).
} 
Table 1. Average Monthly Earnings at main job of occupied population 16 years or older.

\begin{tabular}{lccrrrrr}
\hline Region & 2004 & \multicolumn{1}{c}{2005} & \multicolumn{1}{c}{2006} & \multicolumn{1}{c}{2007} & \multicolumn{1}{c}{2008} & \multicolumn{1}{c}{2009} & \multicolumn{1}{c}{2011} \\
\hline Brazil & $1,007.68$ & $1,043.71$ & $1,127.58$ & $1,170.46$ & $1,197.75$ & $1,231.56$ & $1,357.84$ \\
North & 780.41 & 803.42 & 865.49 & 934.61 & 940.49 & 985.38 & $1,067.22$ \\
Northeast & 566.77 & 590.78 & 664.76 & 682.43 & 726.74 & 760.33 & 848.52 \\
Southeast & $1,245.6$ & $1,289.6$ & $1,385.48$ & $1,419.14$ & $1,427.75$ & $1,457.84$ & $1,603.35$ \\
South & $1,119.33$ & $1,151.6$ & $1,222.12$ & $1,286.72$ & $1,332.61$ & $1,380.37$ & $1,468.88$ \\
Center-West & $1,220.96$ & $1,277.92$ & $1,352.02$ & $1,451.23$ & $1,504.83$ & $1,504.43$ & $1,707.97$ \\
\hline
\end{tabular}

Note: R\$ of 09/2013 - INPC.

Source: IBGE/PNAD.

Figure 1. Mean Monthly Earnings at main job of occupied population 16 years or older.

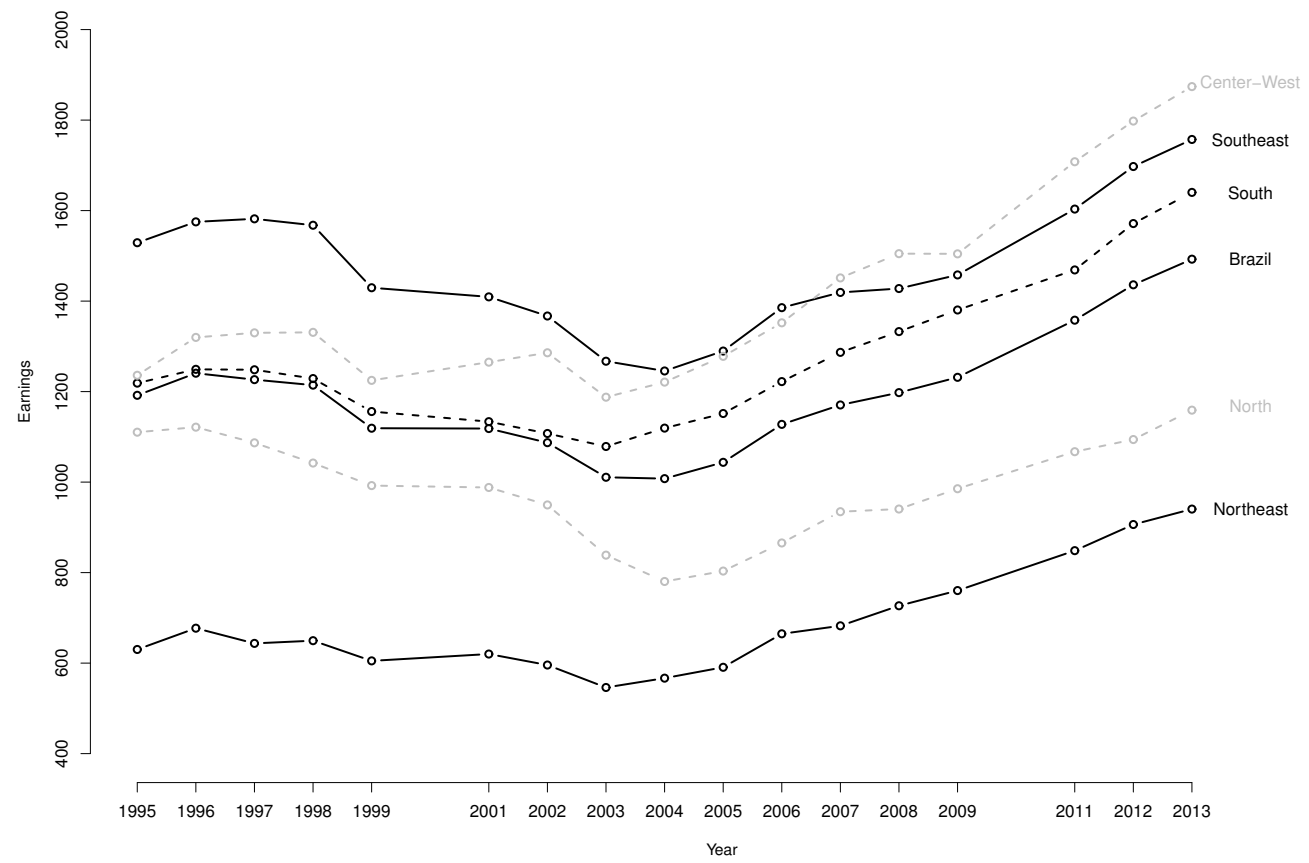

Many Brazilian authors suggest inequality of human capital distribution as the main explanation for that situation (see, among others, Reis \& Barros, 1990, Barros \& Mendonça, 1995, Duarte, Ferreira, \& Salvato, 2004, and Barros et al., 2006). Table 2 presents the mean number of years of education by region. Overall, these figures support the human capital explanation for wage income inequality among regions. However, as many others have argued convincingly other explanations like unionization (Arbache, 1999), quality of education (Behrman \& Birdsall, 1983), bargaining and mark-up power (Amadeo, 1994), and individual unobserved heterogeneity (Freguglia \& Menezes-Filho, 2012) are important to understand wages differences.

\subsection{Unemployment Rate Differences}

Although the question of regional labor income inequality was the interest of Brazilian scholars, the understanding of regional unemployment differences has received much less attention (see, Corseuil, Gonzaga, \& Issler, 1997, Oliveira \& Cruz, 2000, and Oliveira \& Carneiro, 2001). The seminal paper by 
Table 2. Mean Years of Education 16 years or older.

\begin{tabular}{lccccccc}
\hline & 2004 & 2005 & 2006 & 2007 & 2008 & 2009 & 2011 \\
\hline Brazil & 6.89 & 7.01 & 7.19 & 7.31 & 7.47 & 7.60 & 8.73 \\
North & 6.28 & 6.47 & 6.65 & 6.82 & 6.97 & 7.11 & 7.13 \\
Northeast & 5.52 & 5.67 & 5.86 & 6.03 & 6.24 & 6.38 & 6.53 \\
Southeast & 7.60 & 7.71 & 7.89 & 8.01 & 8.11 & 8.23 & 8.39 \\
South & 7.39 & 7.50 & 7.64 & 7.68 & 7.90 & 8.00 & 8.04 \\
Center-West & 7.13 & 7.29 & 7.46 & 7.55 & 7.76 & 7.90 & 8.17 \\
\hline
\end{tabular}

Source: PNAD/IBGE.

Corseuil et al. (1997) presents an analysis of local and national unemployment rates. The authors attempt to measure how aggregate shocks in the Brazilian economy impact on regional labor markets. Corseuil et al. (1997) depart from three basic premises: the sensitivity of regional unemployment with respect to shocks at the national employment; decomposition of regional unemployment into aggregate, regional and industry factors; and fluctuations in regional unemployment.

They draw to main conclusions: i) aggregate shocks are more important than structural regional shocks to explain unemployment dynamics; and ii) it is not easy to define in a clear and unambiguous way whose region has greater natural unemployment rate. So, although Corseuil et al. (1997) are a benchmark in the national literature about regional differences in unemployment dynamics, it falls short over achieving a clear regional explanation for unemployment dynamics. In light of this fact, we resort to more simple empirical evidence in order to have a glimpse on some sort of regional unemployment differences. Table 3 and Figure 2 give us some hints.

A first clear trend is the constant decline on unemployment rate over all regions under analysis. A second, and in a sense, dissapointing pattern, is the fact that for Bahia, Pernambuco (both at the Northeast region) and São Paulo (Southeast region), unemployment rates stay higher than the national level all over the years from 2004 up to 2010. So, this signals that any sort of regional disparity in unemployment rate would be a little hard to back up. Notwithstanding that, we could tentatively try to support a view that Southwestern states like Rio de Janeiro and Minas Gerais (with the exception of São Paulo) have lower unemployment rates than those states in the Northeast.

\subsection{Productivity Differences}

The 1990s brought an unprecedent period of structural change in Brazil's economy. The process of openness of Brazilian economy prompted many changes in the industrial sector, bringing the necessary productive modernization and technological gains in order to be competitive at a global level (see, Feijó \& Carvalho, 2002, Galeano \& Wanderley, 2013a, 2013b). In terms of labor productivity, at first we saw considerable gains overall. However, these initial gains faded away by the beginning of the 2000s. According to Galeano \& Wanderley (2013a), the decrease in labor productivity that started around 19982000 was due mainly to the considerable growth on the number of occupied workers.

The first decade of the 21st century witnesses, from 2002 on, first a fall in labor productivity driven by a decrease on the value of industrial transformation coupled with a increment on the number of occupied workers. From 2002 up to 2005, the growth rate of labor productivity was zero, although we saw a little recovery by the end of the decade. By 2007-2008, labor productivity reached the same value as of 1996. Such evidence of a falling labor productivity prompted some authors to question the very process of openness of Brazilian economy as a beneficial one (see, among others, Galeano \& Wanderley, 2013a, 2013b, Schettini \& Azzoni, 2013, and Cavalcante \& De Negri, 2014).

Despite the controversial impact of trade openness in labor productivity growth, there is some consensus among Brazilian scholars (Galeano \& Wanderley, 2013a, 2013b; Schettini \& Azzoni, 2013) over the 
Table 3. Unemployment Rate.

\begin{tabular}{lrrrrrrrr}
\hline Metropolitan Area & 2004 & 2005 & 2006 & 2007 & 2008 & 2009 & 2010 & 2011 \\
\hline Salvador - Bahia & 16.03 & 15.38 & 13.57 & 13.43 & 11.36 & 11.37 & 10.79 & 9.23 \\
Belo Horizonte - Minas Gerais & 10.63 & 8.98 & 8.57 & 7.35 & 6.43 & 6.39 & 5.39 & 4.68 \\
Recife - Pernambuco & 12.68 & 13.41 & 13.96 & 11.78 & 8.97 & 9.84 & 8.46 & 6.20 \\
Rio de Janeiro - Rio de Janeiro & 9.03 & 7.81 & 7.83 & 7.09 & 6.75 & 5.96 & 5.53 & 5.30 \\
Porto Alegre - Rio Grande do Sul & 8.64 & 7.50 & 8.12 & 6.97 & 5.83 & 5.42 & 4.46 & 4.44 \\
Sao Paulo - Sao Paulo & 12.63 & 10.44 & 10.60 & 9.88 & 8.53 & 8.91 & 6.73 & 6.09 \\
Brazil & 11.48 & 9.83 & 9.98 & 9.29 & 7.89 & 8.08 & 6.74 & 5.98 \\
\hline
\end{tabular}

Source: IpeaData.

Figure 2. Unemployment Rate.

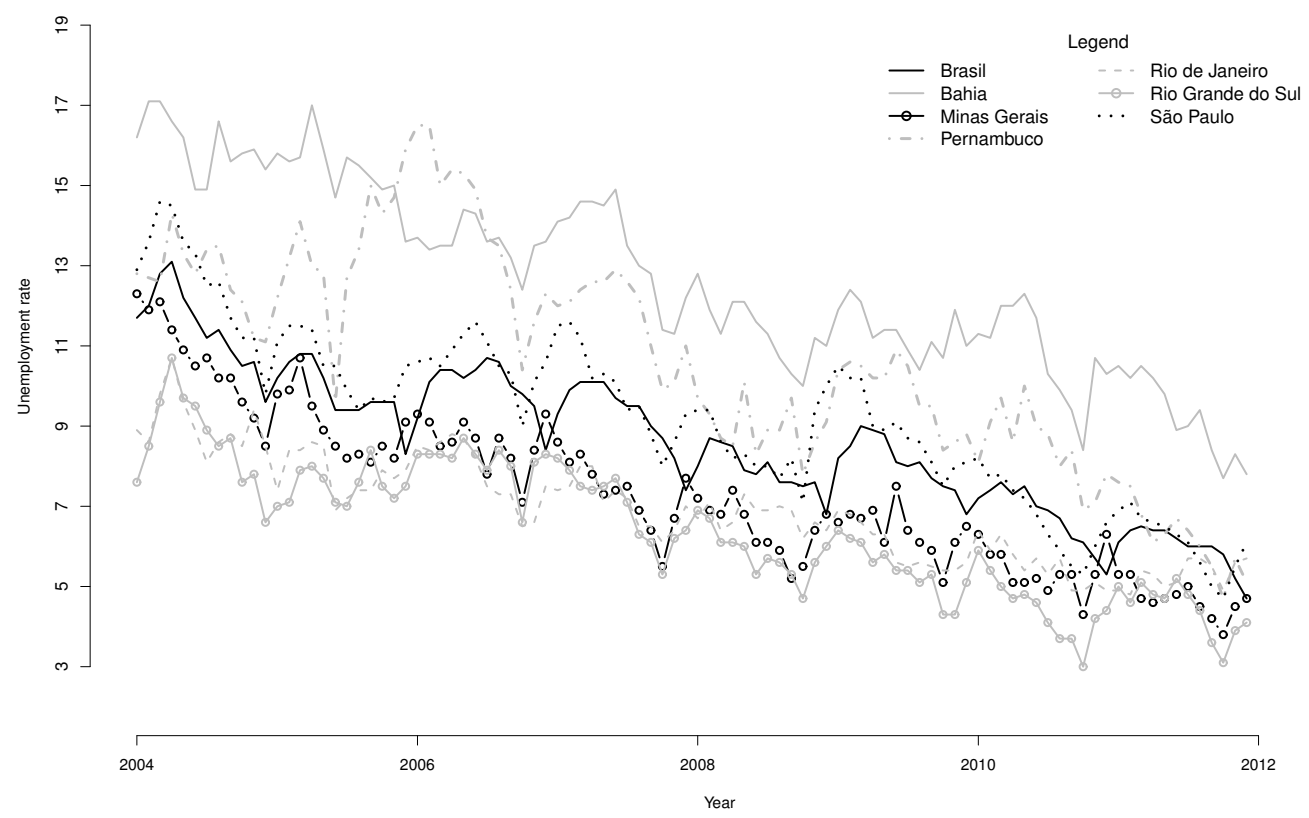

regional impacts, say, spatial reallocation of industrial activity among regions of Brazil. The main effect was a deconcentration of industrial activity from the South and Southeast regions towards North and, mainly, Northeast regions. Actually, the growth rate of labor productivity from the Southeast region was lower than those of all other regions, contributing to slow down the process of regional inequality.

Notwithstanding that increase in labor productivity of all regions vis a vis the more developed Southeast region, with the exception of the North region (whose industry is driven mainly by a massive program of fiscal incentives and "Zona Franca de Manaus" in the state of Amazonas) there is an important gap on labor productivity (see Table 4). Of course, a gap in labor productivity is well known for having deep impacts on growth and development and for posing an obstacle to regional development, since at least Kaldor (1970).

Hence, the question of regional labor inequalities is both pervasive and last longing in Brazil, with deep historical roots but driven by internal and external macroeconomic shocks, as any modern and complex economy. It presents itself by inequalities in wages, unemployment rate and labor productivity, although a key aspect of our paper is to show that such picture can be much more nuanced as long 
Table 4. Industrial Labor Productivity in 2010.

\begin{tabular}{lcc}
\hline & $\begin{array}{c}\text { Extractive } \\
\text { Industry }\end{array}$ & $\begin{array}{c}\text { Transformation } \\
\text { Industry }\end{array}$ \\
\hline Brazil & 145.64 & 26.97 \\
North & 448.44 & 37.21 \\
Northeast & 57.78 & 19.69 \\
Southeast & 156.84 & 30.81 \\
South & 18.15 & 21.87 \\
Center-West & 86.38 & 24.59 \\
\hline
\end{tabular}

Notes: $1,000 \mathrm{RS}$ of 1996

Source: Galeano \& Wanderley (2013b).

as our econometric estimation exercises shed light on the deep relationships brought by the modern search theory. Next section briefly digresses over the empirical implementation of equilibrium search models.

\section{EMPIRICAL IMPLEMENTATION OF JOB SEARCH MODELS}

We start by summarizing the two main different approaches that lead to wage dispersion in job search models as a response to Diamond (1971)'s degeneracy of the wage offer distribution. The first approach is represented by the model by Albrecht \& Axell (1984). The wage dispersion occurs at Albrecht \& Axell (1984) due to the fact that workers are heterogeneous with respect to the value attributed to leisure (or the opportunity cost of labor). Thus, workers differ in the value of reservation wage. By offering a higher wage, the firm increases the level of employment in steady state, but reduces the profit per worker. It is, then, possible that firms which offer different wages have equal profits, enabling the existence of an equilibrium with wage dispersion. Therefore, in this model, the support of the wage offer distribution is equal to a subset of the reservation wages of workers.

The second approach is based mainly on Burdett \& Mortensen (1998). The main result of Burdett \& Mortensen is an equilibrium with wage dispersion even if workers and firms are identical. The dispersion is produced by the possibility of on-the-job search. Firms can offer wages which are higher than the reservation wage because it would also attract more workers from other employers. That is, the labor supply curve for the firm is upward sloping. Thus, using the isoprofit assumption for firms that offer different wages, it is possible to get an equilibrium where the wage distribution is not degenerate on the common reservation wage, avoiding the Diamond (1971) paradox. Finally, the model by Burdett \& Mortensen (1998) is characterized as a model of wage posting. In other words, firms unilaterally decide the wage offer and bargaining between workers and employers will not occur.

As to the empirical evidence, the work by Eckstein \& Wolpin (1990) is based on Albrecht \& Axell (1984) model and the study by van den Berg \& Ridder (1998) is one of the main empirical analysises made from Burdett \& Mortensen (1998) model. In Eckstein \& Wolpin (1990), workers are homogeneous in terms of productivity and heterogeneous in leisure value and firms differ in efficiency in terms of labor productivity. The authors estimate the unrestricted and restricted model. The restricted model incorporates the impositions generated by the equilibrium job search model. Eckstein \& Wolpin (1990) observe that the restricted model fails to explain wage dispersion, which was the main objective of the model. The wage dispersion is almost entirely attributed to measurement error in wages. However, the paper has great appeal because it is the first to develop a methodology to estimate an equilibrium search model of the labor market. Another important feature of the model is that the arrival rate of wage offers is endogenous, determined by the number of active firms. The approach based on the model developed by Burdett \& Mortensen (1998) assumes that this rate is exogenous. 
The study by van den Berg \& Ridder (1998) follows Burdett \& Mortensen (1998) model. The authors consider that the labor market is segmented in relation to some characteristics of workers and, in turn, each segment can be considered a labor market. Thus, it is considered that in each segment workers and firms are homogeneous, but there is heterogeneity between markets. This heterogeneity is important to adjust the model to data. The analysis is performed from a panel data of employed and unemployed workers in the Netherlands. From the estimates of the theoretical model's parameters, the authors estimate the degree of monopsony in firms, effects of minimum wages variations and the factors that determine the wage dispersion. The degree of monopsony is estimated between $10 \%$ and $17 \%$. Employed workers have a high arrival rate of wage offers that influences the competition by firms, reducing their power. Moreover, the results indicate that only $22 \%$ of the observed wage dispersion is explained by the friction in the labor market.

Bontemps et al. (2000) extend the Burdett \& Mortensen (1998) model by assuming that firms are heterogeneous in terms of labor productivity and introduce a continuous distribution of firms' productivities. These authors argue that in reality firms use different technologies and that the assumption of identical firms generates a theoretical distribution of wages with an increasing density, which would be as opposed to data which shows that the highest wages occur at a low frequency. Moreover, the authors do not allow the workers to be heterogeneous due to the fact that, from the evidence of Eckstein \& Wolpin (1990), this type of heterogeneity explains a small fraction of the variation in wages. Then, the wage dispersion is caused by search friction in the labor market and the difference in the firms' productivity.

The model is estimated by a nonparametric method consisting of three stages and has the advantage of the frictional parameters being estimated consistently independent from the strategy that firms adopt. The model is estimated for some sectors of the French economy (transportation, food, equipment, etc.) using microdata from workers and confronting the results with data from employers. The results indicate that firms exploit friction in the labor market, implying a high monopsony power of firms $(20 \%$ to $100 \%)$.

Sulis (2008) estimates the model developed in Bontemps et al. (2000) using data from workers in Italy. The results indicate that the arrival rate of wage offers are higher for unemployed workers. Monopsony power is estimated to be considerably high, ranging between $50 \%$ to $100 \%$. Kyyrä (2007) estimates various specifications of Burdett and Mortensen's model from Finland's microdata. The author estimates the pure homogeneity model, also considering the possibility of measurement error in wages, and the model with heterogeneity in firms' productivity. In the latter case, the author considers the case of discrete and continuous dispersion in type of firms. The results indicate that the model without heterogeneity fits the data for wages only after the introduction of measurement error in wages.

Despite the advance of equilibrium models with wage posting, Mortensen (2003) finds evidence that rejects the model by Bontemps et al. (2000) to Denmark. The productivity levels are overestimated, generating a high level of monopsony for firms. Moreover, the theoretical restriction that the relationship between wages and productivity should be increasing is not satisfied, in other words, that more productive firms offer higher wages. Thus, Mortensen (2003) investigates the possibility that wages are formed through a process of bilateral bargaining. The author suggests this possibility because Denmark has a long history of collective bargaining. The results for this case are admissible for all wages and the estimated levels of productivity are plausible.

For Brazil, analysises of job search models are almost nonexistent. In terms of structural estimation, we can cite the work by Carvalho (2012). The analysis is performed using the microdata from the Survey on Living Standards (PPV), held in 1996 and 1997. Carvalho estimated a search model based on the study of van den Berg \& Ridder (1998), but using retrospective duration data. The author uses the results to analyze differences between labor markets in the Northeast and Southeast regions. There is a low arrival rate of wage offers for employed workers in both regions. In terms of productivity, a lower level of productivity for the Northeast region is estimated. 


\section{EMPIRICAL ANALYSIS}

We use empirical data from six metropolitan areas that are covered by the Monthly Employment Survey (PME). From this data, the parameters of the theoretical models are estimated. Although our paper is an empirical one, it is necessary to summarize the theoretical support for the estimable econometric model. Our approach is based on Bontemps et al. (2000), with the possibility of wage determination presented by Mortensen (2003). The model is an extension of Burdett \& Mortensen (1998) model, where workers and firms are homogeneous.

\subsection{Theoretical Background}

Our approach is based on the model developed by Bontemps et al. (2000), also incorporating the wage determination possibility described by Mortensen (2003). The model is an extension of Burdett \& Mortensen (1998) model, where workers and firms are homogeneous. Bontemps et al. (2000) incorporate the possibility of heterogeneity in the firms' productivity as an attempt to obtain a better fit for the wage distribution. The assumptions of the model are:

A1. Workers and active firms are represented by a continuum of mass 1 and $m$, respectively; they are homogeneous with respect to the ability and the firms are heterogeneous in terms of productivity;

A2. Unemployed worker has a utility flow (discounted search costs) equal to $b$ and workers receive wage offers from a distribution $F(w)$ (known) at a rate $\lambda_{0}$ and $\lambda_{1}$ when unemployed and employed, respectively;

A3. The wage offer distribution, $F(\cdot)$, is independent of the worker's state (employed or unemployed) and the support of $F$ is denoted by $\operatorname{supp}(F)$, where $\underline{w}=\inf (\operatorname{supp}(F))$ and $\bar{w}=\operatorname{supp}(\operatorname{supp}(F))$;

A4. An employed worker leaves the job to unemployment at rate $\delta$, which is called the rate of employment separation (quit rate) and workers and firms discount the future at a rate $\rho$.

Once hypotheses are presented, the next step is to define the strategies used by workers and firms, and define the equilibrium of the model that serves as a basis for empirical analysis.

\subsubsection{Workers}

From the worker's maximization problem and considering the previous assumptions, the value function for an employed worker, $V^{e}(w)$, can be written as

$$
\rho V^{e}(w)=w+\lambda_{1} \int_{w}^{\bar{w}}\left(V^{e}(\tilde{w})-V^{e}(w)\right) d F(\tilde{w})+\delta\left(V^{u}-V^{e}(w)\right),
$$

where $V^{u}$ is the value to be unemployed. Basically, this equation relates with the value of the employment state to the wage that the worker is receiving, plus the additional expected value of a wage offer that exceeds the value of the current wage plus the expected value associated with the return to the state of unemployment, which is negative. Furthermore, we have:

$$
\frac{\partial V^{e}(w)}{\partial w}=\frac{1}{\rho+\delta+\lambda_{1}(1-F(w))}>0
$$

i.e., $V^{e}(w)$ is increasing in $w$.

The value flow for an unemployed worker is

$$
\rho V^{u}=b+\lambda_{0} \int_{0}^{\bar{w}} \max \left\{V^{e}(\tilde{w})-V^{u}, 0\right\} \mathrm{d} F(\tilde{w}) .
$$


Since $V^{e}(w)$ is increasing, there is a reservation wage, $w^{r}$, making $V^{e}\left(w^{r}\right)=V^{u}$. That is, there is a determined wage that makes the worker indifferent between accepting a job and remaining unemployed. ${ }^{3}$ Thus, from (1) and (3) we arrive at

$$
w^{r}=b+\left(k_{0}-k_{1}\right) \int_{w^{r}}^{\bar{w}} \frac{\bar{F}(\tilde{w})}{\beta+1+k_{1} \bar{F}(\tilde{w})} \mathrm{d} \tilde{w},
$$

where $k_{0}=\lambda_{0} / \delta, k_{1}=\lambda_{1} / \delta, \beta=\rho / \delta, \bar{F}(x) \equiv 1-F(x)$. Note that in the definition of the reservation wage, the worker takes into account not only the flow of utility to be unemployed, but the arrival rates of job offers, the separation rate and the wage distribution in the economy. Before presenting the firms' strategy, it is necessary to comment on worker flows in steady state.

\subsubsection{Steady-State Flows}

Steady-state worker flows into and out of unemployment must be equal. Thus, we have that at any time $\lambda_{0} u$ workers leave the unemployment state ${ }^{4}$ and $(1-u) \delta$ fall in unemployment, where $u$ is the measure of unemployed workers. The dynamics of unemployment is given by

$$
\dot{u}=(1-u) \delta-u \lambda_{0} .
$$

At steady state, $\dot{u}=0$. So

$$
u \lambda_{0}=(1-u) \delta \quad \Leftrightarrow \quad u=\frac{1}{1+k_{0}} .
$$

Therefore, this equation relates the unemployment rate with the duration $\left(\lambda_{0}\right)$ and incidence $(\delta)$.

Moreover, the wage distribution in the stock of employed workers is denoted by $G(\cdot)$, where $E(w)=$ $(1-u) G(w)$ is the fraction of individuals receiving a wage less than or equal to $w$ in the stock of employed worker. The dynamics of $E(w)$ is

$$
\dot{E}(w)=\lambda_{0} F(w) u-\delta E(w)-\lambda_{1}(1-F(w)) E(w),
$$

where $\lambda_{0} F(w) u$ is the fraction of unemployed workers who find a job and receive a wage less than or equal to $w, \delta E(w)$ is the fraction of employed workers receiving a wage less than or equal to $w$ and entering the unemployment state and $\lambda_{1}(1-F(w)) E(w)$ is the fraction of employed workers who receive a wage less than or equal to $w$ and find another job that pays more than $w$.

Again, at steady-state $\dot{E}(w)=0$, implying that

$$
G(w)=\frac{F(w)}{1+k_{1}(1-F(w))} .
$$

Equation (8) establishes the structural relationship between the wages distribution earned by the stock of employed workers or earnings distribution, $G(\cdot)$, and the wage offer distribution, $F(\cdot)$.

Based on these relations, we can develop the analysis for the firm's behavior. We will analyze two types of wage determination: i) wage posting, where the firm unilaterally sets the wage; and ii) Nash bargaining, where, after workers and firms meet in the market, they bargain over the wages to be paid by the firm.

\footnotetext{
${ }^{3}$ It is assumed that the worker accepts a job when he/she is indifferent.

${ }^{4}$ In equilibrium, no firm posts a wage below the reservation wage of the worker, which implies that $\bar{F}\left(w^{r}\right)=0$. Therefore, the risk of leaving the state of unemployment is equal to $\lambda_{0}$.
} 


\subsubsection{Wage Posting}

In the wage posting setting, firms determine wages and, given these wages, each firm faces a labor supply curve, $l(w)$. The employment level of a firm that offers a wage $w$ is

$$
\begin{aligned}
l(w) & =\lim _{\epsilon \rightarrow 0} \frac{1-u}{m} \frac{G(w)-G(w-\epsilon)}{F(w)-F(w-\epsilon)}=\frac{1-u}{m} \frac{\mathrm{d} G(w)}{\mathrm{d} F(w)} \\
& =\frac{1-u}{m} \frac{1+k_{1}}{\left[1+k_{1}(1-F(w))\right]^{2}},
\end{aligned}
$$

where $(1-u)(G(w)-G(w-\epsilon))$ is the fraction of employed workers who are receiving a wage in the range $[w-\epsilon, w]$, and $m(F(w)-F(w-\epsilon))$ is the fraction of firms offering a wage in the range $[w-\epsilon, w]$. This equation says that the fraction of workers who receive a wage $w$ are uniformly distributed among firms that offer these wages. When $k_{1}=0$ (no on-the-job search), all firms have the same work force in equilibrium, which equals $(1-u) / m$.

Firms may differ in terms of labor productivity $p$, and $p$ 's distribution is denoted by $\Gamma_{0}(p)$ with $\underline{p}_{0} \geq 0$ being the infimum of its support and $\bar{p}$ the supreme. Assume that $E_{\Gamma_{0}}(p)<\infty$.

It is considered that a worker generates a revenue flow equal to $p$ and is independent of the number of workers in the firm. Thus, $p$ is the labor productivity at the firm and the firm is of type $p$. The firm's objective is to maximize the profit flow at steady state:

$$
\pi(p, w)=(p-w) l(w)
$$

Bontemps et al. (2000) show that in the case of a continuous distribution of firms' productivities, there is a function $K$ that maps $\operatorname{supp}(\Gamma)$ on $\operatorname{supp}(F)$ such that the set $K_{p}$ is represented by a single point $K(p)$. So the first order condition for the profit maximization problem of the firm is

$$
-\left[1+k_{1}(1-F(w))\right]+2 k_{1} f(w)(p-w)=0,
$$

under the restriction that $w \geq \max \left\{w^{r}, w_{\min }\right\}$, where $w=K(p)$. Firms with the lowest possible level of productivity will offer a wage $\underline{w}$. The second order condition is

$$
f^{\prime}(w)\left[1+k_{1}(1-F(w))\right]-k_{1} f(w)^{2}<0,
$$

which is equivalent to saying that $f(w)\left[1+k_{1}(1-F(w))\right]$ is decreasing. This implies that the theory can be tested. For the model to be admissible, a second order condition must be satisfied for all wages in the sample.

Bontemps et al. (2000) derive the following expression for $K(p)$ :

$$
K(p)=p-\left(1+k_{1} \bar{\Gamma}(p)\right)^{2} \int_{\underline{w}}^{p} \frac{\mathrm{d} x}{\left(1+k_{1} \bar{\Gamma}(x)\right)^{2}} .
$$

This is the fundamental equation of the model, because it defines the firms' strategy. That is, the wage offer is a function that depends on the firm's productivity, the level of friction in the labor market $\left(k_{1}\right)$ and the distribution of active firms' productivity. Using the structural relation between $G(\cdot)$ and $F(\cdot)$, we can rewrite (13) as

$$
K^{-1}(w)=w+\frac{1+k_{1} G(w)}{2 k_{1} g(w)} .
$$

Therefore, the structural parameters of the model are necessary to infer the productivity level associated with a given wage. Given the model solution for the case of monopsonistic firms, we proceed now to describe the solution to the case of bilateral bargaining between firms and workers. 


\subsubsection{Nash Bargaining}

Mortensen (2003) suggests that the hypothesis that wages are unilaterally determined by firms may not be admissible. Another feature of the wage posting model is to infer high levels of firms' productivities (Shimer, 2006). So another alternative for wage determination is the possibility that it might be the result of a Nash bargaining process between workers and firms. This process may occur as a result of the presence of unions and classes in the labor market, which is not a very unrealistic assumption for Brazilian labor markets. For example, Mortensen (2003) finds empirical evidence that the appropriate model for Danish data is the bargain. Obviously, this result does not necessarily apply to all economies.

The analysis is somewhat different from the previous problem. First, we can write the value function of a type $p$ firm that pays a wage equal to $w$ as

$$
\rho J(p, w)=p-w-\left(\delta+\lambda_{1} \bar{F}(w)\right) J(p, w) .
$$

Note that it is assumed that the value of a vacant position not occupied is zero (free entry condition). Rewriting (15), we have

$$
J(p, w)=\frac{p-w}{\rho+\delta+\lambda_{1} \bar{F}(w)} .
$$

The value functions for employed and unemployed workers remain the same as those in section 4.1.1. After workers and firms meet, the wage is defined as the Nash solution of the bilateral bargaining process in respect of the surplus value of $V^{e}(w)-V^{u}$, for workers and $J(p, w)$, for firms, since the value of staying with the position not occupied is zero for the firm. I.e.,

$$
\mathcal{W}(p)=\underset{w \geq w^{r}}{\arg \max }\left(V^{e}(w)-V^{u}\right)^{\alpha} J(p, w)^{1-\alpha},
$$

where $\alpha \in(0,1)$ represents the bargaining power of workers. Thus, the first order condition for an interior solution is

$$
\alpha \frac{V^{e^{\prime}}(w)}{V^{e}(w)-V^{u}}-(1-\alpha)\left(\frac{1}{p-w}-\frac{\lambda_{1} f(w)}{\rho+\delta+\lambda_{1} \bar{F}(w)}\right)=0,
$$

where $w \equiv \mathcal{W}(p)$. Again, $p=\underline{w}$, which implies that $\mathcal{W}(p)=\underline{w}$ since this is the only viable wage for the firm that could be accepted by the worker. Note that the "external option" for the worker is $V^{u}$, independent of the individual being unemployed or employed. This is because the bargaining process is ex post and as soon as the worker accepted the job, the only external option is unemployment. In other words, workers cannot return to previous employment. Moreover, it is assumed that workers observe the firm's productivity level when they find a job and thus can infer the resulting wages if they accept the job. Thus, if $\mathcal{W}(p)$ is increasing, employed workers only change to more productive firms.

The inverse function, $\mathcal{W}^{-1}(w)$, obtained from the wage offer function, $\mathcal{W}(p)$ can be derived from (18) as

$$
p \equiv \mathcal{W}^{-1}(w)=w+\frac{1}{\frac{\alpha}{1-\alpha} \frac{V^{e^{\prime}}(w)}{V^{e}(w)-V^{u}}+\frac{\lambda_{1} f(w)}{\rho+\delta+\lambda_{1} \bar{F}(w)} .}
$$

This function relates with the productivity level $p$ associated with a given wage $w$ generated from (17).

Moreover, using the fact that $V^{e}\left(w^{r}\right)=V^{u}$, it follows that from (2) the surplus that the worker obtains from the matching is

$$
V^{e}(w)-V^{u}=\int_{w^{r}}^{w} \frac{1}{\rho+\delta+\lambda_{1} \bar{F}\left(w^{\prime}\right)} \mathrm{d} w^{\prime} .
$$


Substituting (2) and (20) in (19), we arrive at

$$
W^{-1}(w)=w+\frac{(1-\alpha)\left(\rho+\delta+\lambda_{1} \bar{F}(w)\right) \int_{w^{r}}^{w} \frac{1}{\rho+\delta+\lambda_{1} \bar{F}\left(w^{\prime}\right)} \mathrm{d} w^{\prime}}{\alpha+\lambda_{1} f(w)(1-\alpha) \int_{w^{r}}^{w} \frac{1}{\rho+\delta+\lambda_{1} \bar{F}\left(w^{\prime}\right)} \mathrm{d} w^{\prime}} .
$$

Again, the model can be tested. As Mortensen (2003) and Shimer (2006) asserted ${ }^{5}$ the model is admissible if $\frac{\partial \mathcal{W}^{-1}(w)}{\partial w}>0$.

So, after describing the two different mechanisms of wage determination, the following subsection details how the empirical analysis was performed. It is divided into the database and econometric analysis.

\subsection{Data Set}

Our analysis is carried out based on a longitudinal microdata from the Monthly Employment Survey (PME) of $2009,^{6}$ which is a database collected by the Brazilian Institute of Geography and Statistics (IBGE). This survey is conducted in six major metropolitan areas of Brazil, namely: Salvador, Recife, Belo Horizonte, São Paulo, Rio de Janeiro and Porto Alegre. The workers who were interviewed answer several questions related to the labor market and demographic characteristics. Some questions are fundamental to the analysis, as job search duration of an unemployed worker, employment duration, wages, labor market position (employed or unemployed).

The sub-sample is obtained after the initial selection of workers who answered all four consecutive interviews in 2009. Individuals who were out of the labor force were excluded because the model allows only two states, employment and unemployment. Individuals were selected from 16 to 55 years old. All workers who were working on some interviews in the public sector, as self-employed, employer or unpaid, or who were in jobs with working hours shorter than 30 hours were excluded from the subsample. Finally, in order to eliminate potential outliers, we excluded wages below $\mathrm{R} \$ 300.00$ (808 observations) $^{7}$ and $1 \%$ higher wages (370 observations) from the subsample. After this cut the final subsample totaled 46,367 workers.

With respect to the generated variables, it was possible to observe that for unemployed workers we obtain the elapsed time of job search until the date of the first interview, ${ }^{8} t_{0 b}$, and calculate the residual time in which the individual remained unemployed for the other three remaining interviews, $t_{0 f}$. If the worker leaves the state of unemployment to employment in this period, we observe the accepted wage, $w_{0}$, which is a realization of the wage offer distribution, $F(w)$. Furthermore, for individuals who responded that they were seeking a job for 5 years or more, ${ }^{9}$ the unemployment durations were treated as left censored, $d_{0 b}=1$ and for those who remained unemployed in remaining interviews the unemployment duration was considered as right censored, $d_{0 f}=1$. Thus, we have $d_{0 b}=0$ on the date of the first interview if the worker is unemployed for less than 60 months and $d_{0 f}=0$ if the unemployed worker leaves the state of unemployment in the three months after the date of the first interview.

For employed workers, we observe the job durations on the date of the first interview, $t_{1 b}$, and wages, $w_{1}$, which is a realization of $G(w)$. Likewise, the time that the worker remained employed in

\footnotetext{
${ }^{5}$ Note that the model by Shimer (2006) differs from Mortensen (2003) model, but produces similar results.

${ }^{6}$ Menezes-Filho \& Picchetti (2000) and Penido \& Machado (2002) also use only one year to perform a duration analysis.

${ }^{7}$ As of January, 2009, the minimum wage was equal to R\$415.00. After the adjustment in February, 2009, the minimum wage rose to RS 465.00 .

${ }^{8}$ For the interested reader we can provide a diagram showing a detailed account for all possible types of labor market dynamics sampled.

${ }^{9}$ Due to the wording of the questionnaire, the job search duration reported by the respondent is limited to 60 months.
} 
relation to other interviews, $t_{1 f}$, is computed. The worker can leave the current job to unemployment, $v=1$, or to another job, $v=0$. Both alternatives are considered and, if the worker stays unemployed less than 1 month before going into another job, it is considered as a job-to-job transition, as it is done in Sulis (2008). Moreover, if the worker remains in the same job during the remaining interviews, the employment duration is right censored, $d_{1 f}=1$.

Table 5 provides descriptive statistics regarding the final subsample. Included are some statistics related to demographic characteristics in order to provide an overview of the composition of each metropolitan market. All metropolitan areas have a male proportion between 53-54\%. In terms of educational level, the structure is similar across regions, except for some differences. São Paulo has the largest proportion of workers with higher education, $12 \%$, while in the metropolitan area of Recife, that proportion is only $5 \%$. The mean age of workers is 33 years, and there is not a significant difference between regions.

Table 5. Descriptive statistics of subsample.

\begin{tabular}{|c|c|c|c|c|c|c|c|}
\hline & Total & Recife & Salvador & $\begin{array}{c}\text { Belo } \\
\text { Horizonte }\end{array}$ & $\begin{array}{l}\text { Rio de } \\
\text { Janeiro }\end{array}$ & $\begin{array}{c}\text { São } \\
\text { Paulo }\end{array}$ & $\begin{array}{l}\text { Porto } \\
\text { Alegre }\end{array}$ \\
\hline Number of workers & 46,367 & 3,272 & 5,380 & 9,333 & 8,377 & 12,564 & 7,441 \\
\hline Employed (\%) & 87 & 83 & 79 & 90 & 88 & 86 & 91 \\
\hline Unemployed (\%) & 13 & 17 & 21 & 10 & 12 & 14 & 9 \\
\hline Men $(\%)$ & 53.81 & 53.55 & 53.75 & 54.61 & 53.67 & 53.38 & 53.81 \\
\hline \multicolumn{8}{|l|}{ Education } \\
\hline Uneducated (\%) & 1 & 1 & 1 & 1 & 1 & 1 & 0 \\
\hline Literacy (\%) & 23 & 21 & 20 & 25 & 24 & 19 & 26 \\
\hline Elementary education (\%) & 20 & 18 & 18 & 22 & 21 & 18 & 24 \\
\hline High School (\%) & 48 & 55 & 54 & 45 & 44 & 50 & 44 \\
\hline University (\%) & 9 & 5 & 7 & 7 & 10 & 12 & 6 \\
\hline Age & 32.93 & 32.79 & 32.87 & 32.28 & 34.48 & 32.35 & 33.09 \\
\hline (std. dev.) & $(10.12)$ & (9.66) & (9.59) & (10.14) & $(2.10)$ & $(10.23)$ & (10.23) \\
\hline \multicolumn{8}{|l|}{ Unemployed } \\
\hline Left censored (\%) & 0.78 & 0.52 & 1.45 & 0.00 & 0.28 & 1.75 & 0.94 \\
\hline Right censored (\%) & 74.21 & 72.03 & 86.27 & 58.18 & 86.91 & 72.74 & 64.59 \\
\hline Incomplete duration; mean & 8.00 & 6.26 & 25.09 & 4.66 & 11.77 & 7.59 & 7.09 \\
\hline (std. dev.) & (8.79) & $(6.97)$ & $(10.91)$ & $(4.5)$ & $(11.52)$ & (6.99) & $(8.22)$ \\
\hline \multicolumn{8}{|l|}{ Employed } \\
\hline Left Censored (\%) & 0.00 & 0.00 & 0.00 & 0.00 & 0.00 & 0.00 & 0.00 \\
\hline Right censored (\%) & 87.93 & 74.81 & 89.33 & 83.95 & 94.42 & 90.13 & 86.59 \\
\hline Incomplete duration; mean & 55.95 & 57.54 & 59.9 & 50.43 & 62.85 & 54.77 & 53.95 \\
\hline (std. dev.) & $(67.28)$ & $(65.74)$ & (71.74) & (63.95) & (72.89) & (65.39) & $(64.78)$ \\
\hline Transitions to Unemployment & 3,364 & 582 & 297 & 898 & 270 & 680 & 637 \\
\hline Transitions to another job & 1,504 & 1,998 & 159 & 443 & 143 & 386 & 275 \\
\hline \multicolumn{8}{|l|}{ Earnings Distribution $G(w)$} \\
\hline Minimum & 300 & 300 & 300 & 300 & 300 & 300 & 300 \\
\hline$P_{10}$ & 465 & 415 & 415 & 465 & 465 & 480 & 465 \\
\hline$Q_{1}$ & 500 & 465 & 465 & 470 & 500 & 600 & 550 \\
\hline$Q_{2}$ & 700 & 505 & 550 & 600 & 700 & 800 & 700 \\
\hline$\widetilde{Q}_{3}$ & 1,000 & 700 & 800 & 915 & 1,000 & 1,200 & 1,000 \\
\hline$P_{90}$ & 1,680 & 1,000 & 1,400 & 1,500 & 1,700 & 2,000 & 1,600 \\
\hline$P_{90} / P_{10}$ & 3.61 & 2.41 & 3.37 & 3.23 & 4.17 & 3.44 & 3.66 \\
\hline Mean & 926.48 & 658.51 & 786.52 & 867.61 & 927.54 & $1,087.44$ & 936.29 \\
\hline (std. dev.) & (751.37) & (406.27) & (647.12) & (699.6) & (765.88) & $(879.76)$ & (681.47) \\
\hline
\end{tabular}

The mean of unemployment duration $\left(t_{0 b}+t_{0 f}\right)$, also considering the incomplete duration, is 8 months in Brazil. Because there are workers who remained unemployed, it is likely to understate the actual mean of unemployment durations. The metropolitan area of Belo Horizonte has the lowest average, 
4.66 months, and Rio de Janeiro has the largest, 11.77. For employed workers on the date of the first interview, the mean of employment duration $\left(t_{1 b}+t_{1 f}\right)$ is 55.95 months. Rio de Janeiro has the highest mean, 62.85, while Belo Horizonte has the lowest, 50.43 months.

Regarding the wage distribution of employed workers on the date of the first interview, we observe a considerable difference between the metropolitan areas studied. The metropolitan region of São Paulo has the highest mean, $\mathrm{R} \$ 1,087.44$, and Recife has the lowest average, $\mathrm{R} \$ 658.51$, which represents only $60 \%$ of the state of São Paulo. Observing the ratio between the ninetieth and tenth percentiles, Recife also has a low-wage dispersion when compared to other metropolitan areas.

Finally, Figure 3 shows kernel estimates of the density functions of the accepted wages distribution by workers who left the unemployment state during the survey, $f(w)$ (wage offer distribution), and the wages distribution earned by workers who were employed at the date of the first interview, $g(w)$ (earnings distribution). Theory predicts that the wage offer distribution is dominated by the earnings distribution, due to the fact that the employed workers can migrate to jobs that pay higher wages. Referring to Figure 3, there is little difference between $f(w)$ and $g(w)$ for the metropolitan areas of Recife and Salvador. However, for other regions, especially for São Paulo and Porto Alegre, there is a considerable difference between these distributions, which may be showing greater mobility of workers to jobs that pay better wages.

\subsection{Structural Estimation}

Job search models are usually estimated by maximum likelihood. In the case of the model in question, the wage offers distribution $F(w)$ does not have an explicit form. Thus, Bontemps et al. (2000) proposed a three-stage procedure to estimate the nonparametric model.

First, we need to specify the likelihood function. The model predicts that the unemployment duration is exponentially distributed with parameter $\lambda_{0}$, due to the fact that the time between two events of a Poisson process is exponentially distributed. The exponential distribution has the characteristic of being memoryless. Thus, this distribution has the property that the elapsed unemployment duration until the date of interview, $t_{0 b}$, and the residual unemployment duration(referring to remaining interviews), $t_{0 f}$, are independent and exponentially distributed ${ }^{10}$ with parameter $\lambda_{0}$. The probability of sampling an unemployed worker at the date of the first interview is equal to $1 /\left(1+k_{0}\right)$ and if he/she receives a wage offer, $w_{0}$, this wage offer will be a realization of $F(\cdot)$. Thus, we can write the likelihood function for an unemployed worker as

$$
\mathcal{L}_{d}=\frac{\lambda_{0}^{2-d_{0 b}-d_{0 f}}}{1+k_{0}} \exp \left[-\lambda_{0}\left(t_{0 b}+t_{0 f}\right)\right] f\left(w_{0}\right)^{\left(1-d_{0 f}\right)},
$$

where $d_{0 b}$ is equal to 1 if $t_{0 b}$ is left censored, and $d_{0 f}$ is equal to 1 if $t_{0 f}$ is right censored.

The probability that an employed worker is observed is equal to $k_{0} /\left(1+k_{0}\right)$ and the wage received $w_{1}$ is a realization of the earnings distribution, $G(\cdot)$. Job duration is exponentially distributed with parameter $\theta$, where $\theta=\delta+\lambda_{1} \bar{F}\left(w_{1}\right)$, given $w_{1}$. The probability that a worker leaves the current job to unemployment or to another job are equal to $\delta /\left(\delta+\lambda_{1} \bar{F}\left(w_{1}\right)\right)$ and $\lambda_{1} \bar{F}\left(w_{1}\right) /\left(\delta+\lambda_{1} \bar{F}\left(w_{1}\right)\right)$, respectively. Again, $t_{1 b}$ and $t_{1 f}$ are the elapsed and residual job duration, respectively, and are assumed to be independent. The likelihood function for an employed worker is

$$
\mathcal{L}_{e}=\frac{k_{0}}{1+k_{0}} g\left(w_{1}\right)\left(\delta+\lambda_{1} \bar{F}\left(w_{1}\right)\right)^{1-d_{1 b}} \exp \left[-\left(\delta+\lambda_{1} \bar{F}\left(w_{1}\right)\right)\left(t_{1 b}+t_{1 f}\right)\right] \times\left[\delta^{v}\left(\lambda_{1} \bar{F}\left(w_{1}\right)\right)^{1-v}\right]^{1-d_{1 f}},
$$

where $d_{1 b}$ is equal to 1 if $t_{1 b}$ is left censored, $d_{1 f}$ is equal to 1 if $t_{1 f}$ is right censored, and $v$ is equal to 1 if the transition is to unemployment and 0 if it is to another job. Therefore, one can write the likelihood

\footnotetext{
${ }^{10}$ For more details see Lancaster (1990) and Cameron \& Trivedi (2005).
} 
Figure 3. Kernel estimates of wage distributions.

(a) Recife

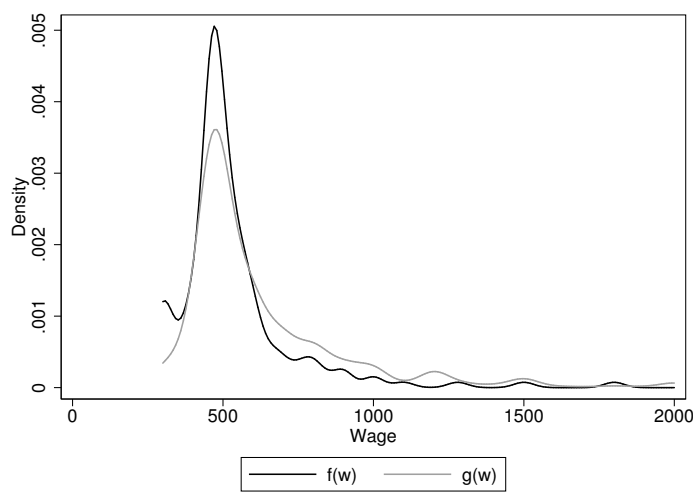

(c) Belo Horizonte

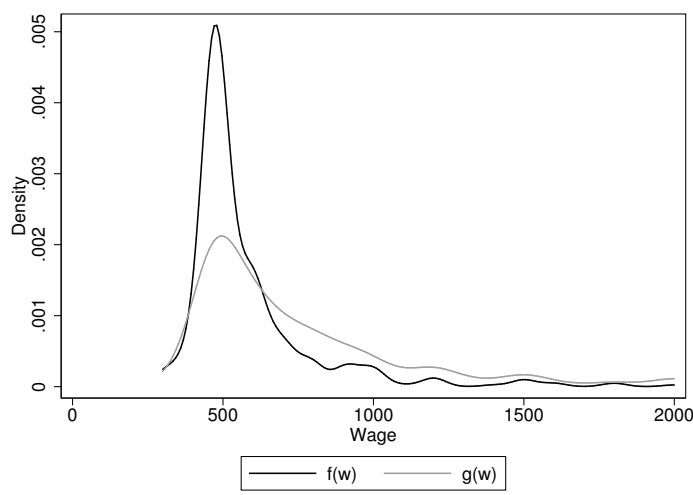

(e) São Paulo

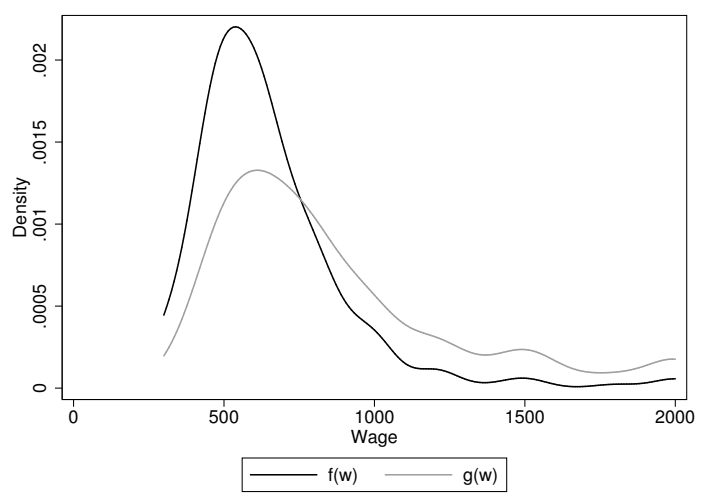

(b) Salvador

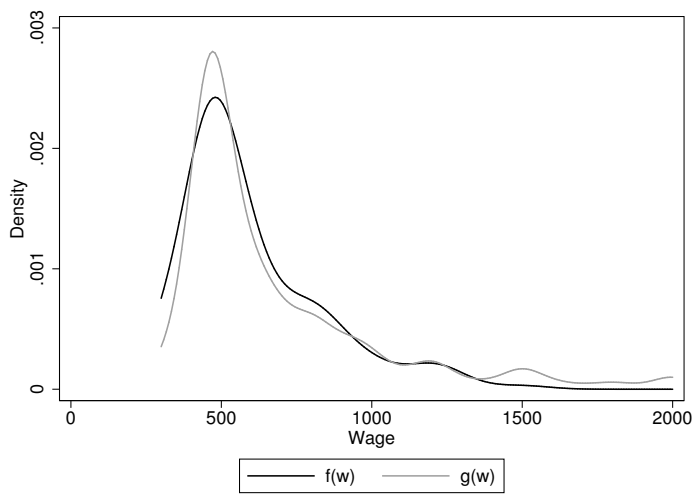

(d) Rio de Janeiro

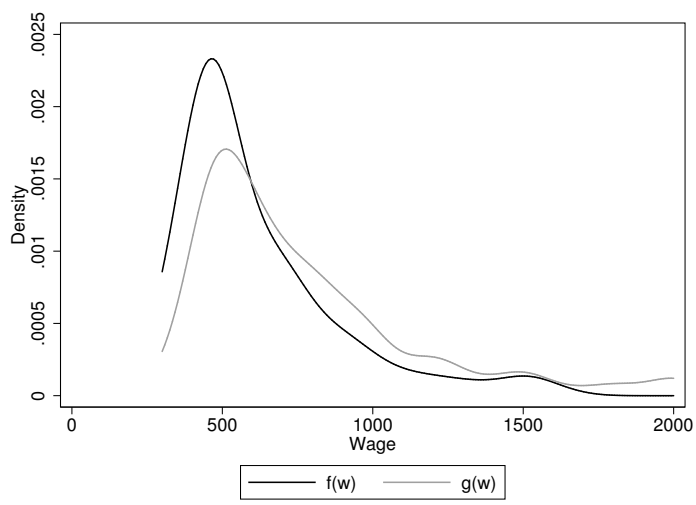

(f) Porto Alegre

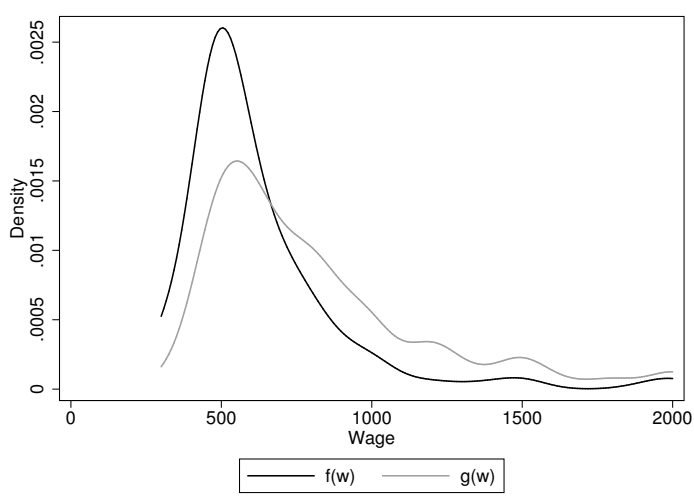


function for a sample of size $N$ as

$$
\mathcal{L}=\prod_{i=1}^{N} \mathcal{L}_{d i}^{x} \mathcal{L}_{e i}^{(1-x)},
$$

where $x$ is equal to 1 if the worker is unemployed at the time of the first interview and 0 if he/she is employed.

Moreover, using the relation between $F(\cdot)$ and $\Gamma(\cdot)$, we can generate the density function of firms' productivities, $\gamma(\cdot)$. Thus, considering that the wage policy function ${ }^{11}$ is $w(p)$, the density function of firms' productivity is

$$
\frac{\mathrm{d} \Gamma(p)}{\mathrm{d} p} \equiv \gamma(p)=f(w) w^{\prime}(p) .
$$

Using the inverse relationship with $w(p)$, we can rewrite (25) as

$$
\gamma(p)=\frac{f(w)}{\left(w^{-1}\right)^{\prime}(w)}
$$

where $\left(w^{-1}\right)^{\prime}(w)=\frac{\partial w^{-1}(w)}{\partial w}$. Therefore, it becomes possible to obtain an expression for $\gamma(p)$ for the two wage determination cases.

As already mentioned, $F(w)$ does not have an explicit form, which makes the use of the likelihood function alone impossible. Thus, we adopt the procedure proposed by Bontemps et al. (2000). To estimate the bilateral bargaining model, we set $\rho=0$. As it is also assumed in Burdett \& Mortensen (1998) in the wage posting model, due to the fact that this parameter cannot be identified from the data. We also set $\alpha=0.5$ and $\widehat{w}^{r}=\min \left\{w_{i}\right\}_{i=1}^{N}$.

Note that by this procedure, the frictional parameters estimation $\left(\lambda_{0}, \lambda_{1}\right.$ and $\left.\delta\right)$, which is held in the first two steps, is based only on worker's behavior. Thus, it is expected that the estimatives of these parameters are consistent with different forms of firms' behavior (Bontemps et al., 2000). Another important point is the fact that for the model not to be rejected by the data it must have $\gamma(p)>0$. Then, from equation (26) wages and productivities must be positively related, which is a restriction generated by the theoretical model. For the estimation of $g(w)$, we use the Gaussian kernel function.

Finally, standard errors or confidence intervals of $\hat{\lambda}_{0}, \hat{\lambda}_{1}$ and $\hat{\delta}$, are obtained using bootstrap replications procedures, including the first stage. The bootstrap method is also useful to generate the confidence interval of $k_{1}=\lambda_{1} / \delta$, serving as an alternative to the delta method. The results follow.

\section{RESULTS}

This section presents the results of the structural estimation of the job search model. The results are divided into two sections. The first presents estimation results for the frictional parameters that are independent of the any wage setting behavior of firms. The second section presents the results for the estimated productivities distribution considering the two possibilities of wage determination.

\subsection{Frictional Parameters}

The frictional parameters are a measure of the search frictions present in the labor market that represent the difficulty of workers and employers to establish working relationships. Table 6 presents the estimatives for the six metropolitan areas that constitutes the PME.

First, the arrival rate of wage offers by unemployed workers, $\lambda_{0}$, shows considerable heterogeneity among the metropolitan areas studied. This rate in the metropolitan area of Belo Horizonte is $22.77 \%$,

\footnotetext{
${ }^{11}$ In the case of wage posting models, $w(p) \equiv K(p)$, and to the bilateral bargain $w(p)=\mathcal{W}(p)$.
} 
Table 6. Estimates of frictional parameters.

\begin{tabular}{lcccc}
\hline & $\begin{array}{c}\lambda_{0} \\
\text { unemployed } \\
\text { arrival rate offer }\end{array}$ & $\begin{array}{c}\lambda_{1} \\
\text { employed } \\
\text { arrival rate offer }\end{array}$ & $\begin{array}{c}\delta \\
\text { separation } \\
\text { rate }\end{array}$ & $\begin{array}{c}k_{1} \\
\text { level } \\
\text { of friction }\end{array}$ \\
\hline Recife & 0.1497 & 0.0089 & 0.0196 & 0.4515 \\
Salvador & {$[0.1361 ; 0.1618]$} & {$[0.007 ; 0.0106]$} & {$[0.0186 ; 0.0205]$} & {$[0.3467 ; 0.5571]$} \\
Belo Horizonte & 0.0898 & 0.0133 & 0.0153 & 0.8670 \\
& {$[0.0849 ; 0.0942]$} & {$[0.0111 ; 0.0159]$} & {$[0.0146 ; 0.016]$} & {$[0.7283 ; 1.0824]$} \\
Rio de Janeiro & 0.2277 & 0.0307 & 0.0164 & 1.8683 \\
& {$[0.2191 ; 0.2397]$} & {$[0.0275 ; 0.0343]$} & {$[0.0158 ; 0.0171]$} & {$[1.6828 ; 2.1442]$} \\
São Paulo & 0.0915 & 0.0209 & 0.0115 & 1.8182 \\
& {$[0.086 ; 0.096]$} & {$[0.0183 ; 0.024]$} & {$[0.0111 ; 0.012]$} & {$[1.536 ; 2.1304]$} \\
Porto Alegre & 0.1284 & 0.0306 & 0.0141 & 2.1697 \\
& {$[0.1234 ; 0.1329]$} & {$[0.0271 ; 0.0337]$} & {$[0.0136 ; 0.0145]$} & {$[1.8963 ; 2.4559]$} \\
& 0.1615 & 0.0311 & 0.0141 & 2.2078 \\
& {$[0.1523 ; 0.1713]$} & {$[0.0271 ; 0.0356]$} & {$[0.0135 ; 0.0146]$} & {$[1.8941 ; 2.6102]$} \\
\hline
\end{tabular}

Notes: $2.5 \%$ and $97.5 \%$ percentiles of bootstrap distribution. 100 replications. Time unit: months.

while in Salvador this rate is only $8.98 \%$, which implies an expected completed unemployment duration $^{12}$ of approximately 11 months. This rate has a direct influence on unemployment rates, because the faster unemployed workers find jobs, the lower is the unemployment rate in the economy, given a level of destruction of employment relations (separation rate).

Compared to other studies, the estimated values of $\lambda_{0}$ in our paper are relatively higher. In Bontemps et al. (2000) this rate is on average 0.07 and in Sulis (2008) this rate ranges between 0.04 to 0.07 , but the author highlights the fact that the measure of unemployment duration used in the study is the time that the worker remains outside the administrative records used, which may be caused by unemployment, employment in public service, self-employment and inactivity. On the other hand, according to Bontemps et al. (2000) the parameters estimated by Kiefer \& Neumann (1993) are two times higher than those estimated by the first authors, which would be closer to the values we have found here.

Regarding the arrival rate of wage offers for employed workers, $\lambda_{1}$, we find that this rate is considerably smaller than $\lambda_{0}$. This is in accordance with the international literature. Compared to other metropolitan areas, Recife has a considerably low level of $\lambda_{1}$, only $0.89 \%$. São Paulo and Porto Alegre have a rate approximately three times greater than Recife's. This fact is already an indication that workers have greater mobility in these metropolitan areas, which implies higher competition among employers.

The separation rate is more homogeneous among the metropolitan areas. On average, approximately $1.5 \%$ of employed workers become unemployed per month. Rio de Janeiro has the lowest separation rate among the regions analyzed, indicating that the labor market in this region has a lower turnover. The results coming from the international literature are distinct. Van den Berg \& Ridder (1998) and Bontemps et al. (2000) estimate a rate on average of 0.005 and 0.0061 for the Netherlands and France, respectively. On the other hand, Sulis (2008) estimated a rate of 0.0128 for Italy and Bunzel et al. (2001) estimate $\delta$ between 0.01 to 0.02 for Denmark, which are closer to those estimated by us. Kyyrä (2007) found high values of $\delta$ for Finland, estimatives of $\delta$ in his work range from 0.05 to 0.01 .

It is about the right place to deepen our analysis and try to connect our estimates with the prevalent regional inequalities in Brazilian labor markets described in section 2. We start by rationalizing regional

\footnotetext{
${ }^{12}$ As the duration of unemployment is assumed distributed exponentially with parameter $\lambda_{0}$, the expected full length is simply equal to $1 / \lambda_{0}$.
} 
inequalities on unemployment rates and the estimated deep parameters of our model, say, $\lambda_{0}, \lambda_{1}$ and $\delta$ on Table 6 . Since $\delta$ is roughly homogenous, we focus on both $\lambda_{0}$ and $\lambda_{1}$. For instance, let us start with Bahia, which presented in 2009, accordingly to Table 3, an unemployment rate of 11.37 and compare it to Porto Alegre (with a 5.42 unemployment rate). Do our structural estimates have a bite on that regional inequality? We think the answer is yes. While Salvador has the lowest rate of wage offer while unemployed (0.0898) and one of the lowest rate of wage offer while employed (0.013), ahead of Recife only, Porto Alegre has almost twice Salvador's wage offer while unemployed $(0.1615)$ and almost three times its rate of wage offer while employed (0.0311). So, no wonder Salvador and Porto Alegre occupy the extremes in terms of unemployment inequality in Brazil. More specifically, from an efficiency point of view any policy aiming improvements on Salvador's unemployment rate must act on its very low arrival of wage offer while employed, something that has to do with its internal labor market.

If we want to draw a more regional explanation here, definitely we would look at the values of $\lambda_{1}$, the arrival rate of wage offer while employed. The second column in 6 brings us an important hint: metropolitan areas belonging to the South and Southeast regions have at least twice, sometimes three times, the corresponding $\lambda_{1}$ of Recife and Salvador, both areas in the Northeast. In other words, the scanty debate about regional differences in unemployment rate can be both backed up and, more importantly, can be deepened with our results, by noting that the inefficiency of internal labor markets in the Northeast is a driving force of that phenomena.

From $\lambda_{1}$ and $\delta$ one can obtain $k_{1}$, which is a parameter of great importance in the model because it is a measure of the level of friction in the labor market (van den Berg \& van Vuuren, 2003). This is because $k_{1}$ measures the number of expected job offers to be received by a worker during an episode of employment, reflecting the level of competition among firms in the market. Hence, in a market that employed workers receive alternative offers at a higher rate, employers have incentives to offer better wages to reduce the outflow of workers. Besides this effect, of course, workers move more quickly into jobs that pay better wages, which implies that the earnings distribution, $g(w)$, tends to dominate the wage offer distribution, $f(w)$. Now, let us step into the regional inequality in wages appearing in Table 1.

The effect of $k_{1}$ on the distributions is evident at Figure 3 (page 87). It is observed that for the metropolitan areas that have lower $k_{1}$ values, the distributions of $f(w)$ and $g(w)$ are closer, which is the case of the metropolitan areas of Recife and Salvador. However, São Paulo and Porto Alegre have values of $k_{1}$, approximately four times higher than that of Recife and the effect is that $g(w)$ moves away from $f(w)$, i.e., workers have a faster wage growth in these regions. Thus, we got some evidence that the higher the level of friction in the market (lower $k_{1}$ ) is, the more concentrated the wage distribution is because workers have a low transition rate to jobs that pay better wages. Hence, our structural estimates corroborate past finds and, again, shed light on the debate: regional inequality in wages, besides being an outcome of its regional human capital distribution, can be rationalized as inequality of labor market search frictions.

How reasonable are our estimates? Table 7 gives us some hints: it shows a comparison between our estimatives ${ }^{13}$ and those estimated in other studies. The estimated value of $\lambda_{0}$ in our paper is considerably higher than those on other studies, but Carvalho (2012) has a value close to that estimated in this study. As explained earlier, some authors make use of nonemployment durations, which include individuals who remained out of the workforce instead of using strictly unemployment duration data. Therefore, it is expected that the nonemployment duration mean be higher than the unemployment duration mean, which is calculated based on those workers who are actively seeking employment. There is also a chance of encountering a memory bias due to the fact that respondents underestimate the actual time they are searching for a job, which contribute to the estimation of high values of $\lambda_{0}$. As to $\lambda_{1}$, our estimatives are only slightly less than the estimated in van den Berg \& Ridder (1998).

\footnotetext{
${ }^{13}$ The values in Table 7 are related to the estimation of the model for the total sample.
} 
Table 7. Comparison of estimated values of frictional parameters.

\begin{tabular}{llcccc}
\hline & Country & $\lambda_{0}$ & $\lambda_{1}$ & $\delta$ & $k_{1}$ \\
\hline Our results & Brazil - PME & 0.129 & 0.022 & 0.015 & 1.467 \\
Van den Berg \& Ridder (1998) & Netherlands & 0.033 & 0.047 & 0.005 & 9.400 \\
Bontemps et al. (2000) & France & 0.063 & 0.008 & 0.006 & 1.333 \\
Bunzel et al. (2001) & Denmark & 0.028 & 0.010 & 0.015 & 0.235 \\
Sulis (2008) & Italy & 0.043 & 0.006 & 0.013 & 0.462 \\
Carvalho (2012) & Brazil - PPV & 0.137 & 0.005 & 0.005 & 1.000 \\
\hline
\end{tabular}

By comparing $k_{1}$, the value found here is close to the estimate for France by Bontemps et al. (2000). However, in van den Berg \& Ridder (1998), the value of $k_{1}$ is estimated at about 9.40, which is considerably high and the authors find a low level of monopsony power by firms. On the other hand, Sulis (2008) estimated a low $k_{1}$ which means high levels of monopsony power.

In the model with homogeneous firms, such as Burdett \& Mortensen (1998), wage dispersion is caused only by search frictions. However, when we include heterogeneity in the firms' productivity, the dispersion is also caused by differences of firms. The next section investigates the productivity distribution from the two possibilities of firms' behavior assumed in this work and trace a parallel between that and regional differences in labor productivity.

\subsection{Productivities Distribution}

As we saw in section 2.3 , the first decade of the 21 st century witnesses a falling labor productivity all over Brazil. Here, we will try to give alternative explanations not for this decline but for the still prevalent regional differences in productivity. The productivity distribution is obtained from the third step of the estimation process (Bontemps et al., 2000). Such step is related to finding the productivity levels associated with observed wages in the sample, exploiting the first order conditions, given the frictional parameters estimated in previous steps. In addition, for each productivity level, we estimate the corresponding value of the density function, $\gamma(p)$ associated to $\Gamma(\cdot)$ which is one of the model's primitive.

This step is performed for each possible wage determination analyzed: bilateral bargaining and wage posting. One of the restrictions shared by both wage determination mechanisms is to observe an increasing relationship between wages and productivities. This condition is satisfied for the bilateral bargaining case, but not wage posting. Mortensen (2003) finds the same result for the labor market in Denmark. This result ${ }^{14}$ can be seen in Figure 4. In the wage posting case, the theory is rejected at lowest observed wages, where the relationship is decreasing, implying that those wages cannot be profits maximizing for firms. That is, the model does not explain the left tail of the wage distribution. The shape of the relationship between wages and productivity is similar to that found by Mortensen (2003, p.103).

Besides the fact of not observing an increasing relationship between wages and productivity, the wage posting model generates implausible values for the firms' productivity levels. Table 8 shows the estimated productivity levels for the stock of employed workers on the date of the first interview. As the largest and most developed metropolis, it is expected that firms in São Paulo have the highest average productivity level. However, the metropolitan area of Recife has the highest average productivity level and after Recife, Salvador has the second highest. This may be due to the fact that estimated productivity

\footnotetext{
${ }^{14}$ It represents the relationship between wages and productivity for the metropolitan region of São Paulo. Other metropolitan areas have an analogous pattern.
} 
Figure 4. Relationship between wages e productivities.

(a) Wage Posting

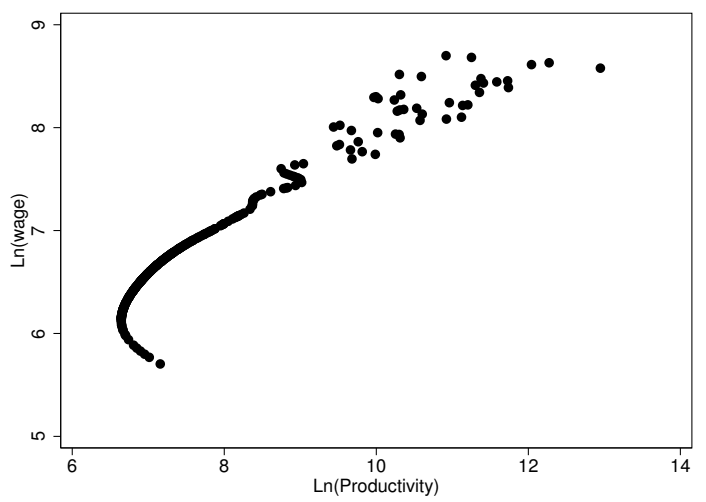

(b) Bilateral Bargaining

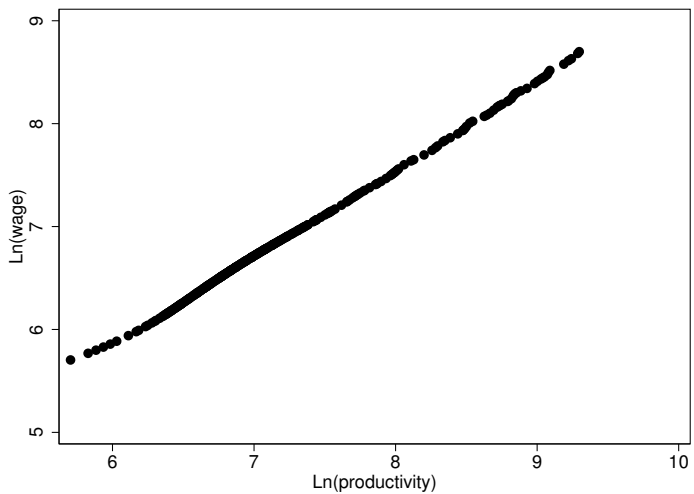

Table 8. Estimated productivities distribution: wage posting.

\begin{tabular}{lcccrccrc}
\hline & Minimum & $P_{10}$ & $Q_{1}$ & \multicolumn{1}{c}{$Q_{2}$} & \multicolumn{1}{c}{$Q_{3}$} & \multicolumn{1}{c}{$P_{90}$} & \multicolumn{1}{c}{$P_{90} / P_{10}$} & Mean \\
\hline Recife & 849.94 & 851.63 & 851.63 & $1,149.04$ & $2,812.47$ & $6,298.05$ & 7.40 & $5,903.52$ \\
Salvador & 730.30 & 748.52 & 748.52 & $1,109.06$ & $2,308.59$ & $8,190.00$ & 10.94 & $5,350.19$ \\
Belo Horizonte & 642.59 & 661.69 & 676.81 & 941.36 & $1,993.42$ & $6,159.22$ & 9.31 & $4,264.10$ \\
Rio de Janeiro & 694.92 & 712.04 & 747.33 & $1,174.25$ & $2,327.15$ & $8,801.40$ & 12.36 & $4,424.64$ \\
São Paulo & 768.79 & 781.69 & 883.96 & $1,268.75$ & $3,139.06$ & $8,156.23$ & 10.43 & $4,147.55$ \\
Porto Alegre & 694.14 & 710.52 & 788.53 & $1,068.96$ & $2,070.59$ & $6,424.08$ & 9.04 & $4,142.61$ \\
\hline
\end{tabular}

Note: $P_{10}, P_{90}, Q_{1}, Q_{2}, Q_{3}$ are percentiles e quartiles.

levels are too high for firms that pay the highest wages and are in the right tail of the distribution. Therefore, as the probability mass at the end of the distribution tends to zero, the estimated productivity level tends to be extremely high, inflating the mean. In Figure 3 (on page 87), we find that the density function of wages to Recife is closer to zero for higher wages than to São Paulo.

Shimer (2006) and Mortensen (2003) noted that the model with wage posting tends to estimate implausible productivity levels. Sulis (2008) also found high values for the estimated productivity and restricts its analysis to qualitative questions. Bontemps et al. (2000) argue that large differences in productivity and wages for some firms are due to the presence of the employer's large capital stock, not treated in the model, which would generate a positive effect on labor productivity. Hence, from now on we stick to the bilateral bargaining model both on empirical grounds and on the Brazilian union structure described, for instance, in Amadeo (1994).

Table 9 shows the estimated productivity distribution for employed workers, considering the case in which wages are determined as a result of a bilateral bargaining process. In this case, the metropolitan area of Recife has the lowest average productivity level, R\$956.46. Now, São Paulo has, on average, the highest estimated labor productivity level, $\mathrm{R} \$ 1,617.22$, approximately $69 \%$ higher than Recife's average. Note that the values are much smaller than those presented in Table 8. In terms of dispersion and considering the ratio between the ninetieth and tenth percentiles, São Paulo and Rio de Janeiro have the greatest productivity dispersion.

An important result is obtained when comparing the metropolitan areas of Rio de Janeiro and Porto Alegre. According to Table 5, the mean wage of an employed worker is R\$927.54 and R\$936.39 for Rio de Janeiro and Porto Alegre, respectively. However, Porto Alegre has a lower average productivity level 
Table 9. Estimated productivities distribution: bilateral bargaining.

\begin{tabular}{lcccccccc}
\hline & Minimum & $P_{10}$ & $Q_{1}$ & \multicolumn{1}{c}{$Q_{2}$} & $Q_{3}$ & $P_{90}$ & $P_{90} / P_{10}$ & \multicolumn{1}{c}{ Mean } \\
\hline Recife & 300.00 & 515.61 & 593.03 & 656.90 & $1,018.52$ & $1,591.67$ & 3.09 & 956.46 \\
Salvador & 300.00 & 507.43 & 581.71 & 717.42 & $1,166.16$ & $2,317.39$ & 4.57 & $1,174.23$ \\
Belo Horizonte & 300.00 & 568.27 & 574.95 & 763.98 & $1,289.42$ & $2,373.75$ & 4.18 & $1,265.98$ \\
Rio de Janeiro & 300.00 & 576.47 & 625.32 & 926.82 & $1,434.59$ & $2,775.68$ & 4.81 & $1,372.77$ \\
São Paulo & 300.00 & 605.46 & 767.02 & $1,056.84$ & $1,757.31$ & $3,164.49$ & 5.23 & $1,617.22$ \\
Porto Alegre & 300.00 & 575.30 & 686.68 & 904.65 & $1,398.28$ & $2,504.62$ & 4.35 & $1,352.76$ \\
\hline
\end{tabular}

Note: $P_{10}, P_{90}, Q_{1}, Q_{2}, Q_{3}$ are percentiles e quartiles.

than that of Rio de Janeiro. Thus, it was expected that workers were better off in the region with more productive firms. However, from Table 6, we have that the level of search frictions in the labor market is higher in Rio de Janeiro than in Porto Alegre. Therefore, workers in this region have a higher transition rate towards more productive firms that pay higher wages. This result is important because it reflects the inefficiency problem due to imperfect information in the labor market, where less productive firms retain workers with low wages even if there are jobs associated with higher levels of productivity and wages. In essence, Table 8 reflects those figures present on Table 4 (page 78). However, our methodology allows us to go further: let us move to the density functions.

The estimated distributions have similar shapes, with a concentration of firms at a low productivity level and a long right tail. ${ }^{15}$ However, for example, it may be noted that the firms' productivities distribution is less dispersed in Recife than it is in São Paulo. And this is crucial to understand the link between firms' productivities, wages and labor market frictions, bringing a new host of possible explanations to regional inequality.

To analyze the difference between the productivity levels and wages received by workers, it is interesting to observe what is called the "monopsony power index". This index is defined by:

$$
\mu(p)=\frac{p-\mathcal{W}(p)}{p},
$$

where $\mathcal{W}(p) \equiv w$. The analysis is performed only for the bargaining model, due to the fact that the wage posting model does not generate acceptable results from the theoretical point of view. This index provides the share of labor productivity that is appropriated by the firm. The index is equal to 0 in the case of wages equal to productivity, and is equal to 1 , in which case the firm appropriates all gains of productivity.

Thus, from the results obtained in the case of wage determination via bilateral bargaining one can infer a lower monopsony power compared to the case where firms post wages, as evidenced by in Bontemps et al. (2000) and Sulis (2008). Part of this difference is explained by the fact that if the firms post wages, they have the full power on the wage determination and the only factor influencing the reduction in their power would be the competition between firms. In the case of bilateral bargaining, apart from the competition with other firms, workers have some power over the wage determination.

Figure 5 shows the monopsony power index for the six metropolitan regions at each productivity level. For lower productivity levels, all regions provide similar values for its monopsony index. In addition to these levels, we find that the resulting wages are closer to the labor productivity value. This is probably because less productive firms experiencing a higher rate of workers outflow, so they react by increasing the wages of workers in order to reduce this outflow. This index grows rapidly up to the productivity level around $\mathrm{R} \$ 2,000$. At this productivity level, the index is approximately $40 \%$

\footnotetext{
${ }^{15}$ The interested reader can obtain the graph for estimated productivities from the authors.
} 
Figure 5. Monopsony Power Index.

(a) Recife

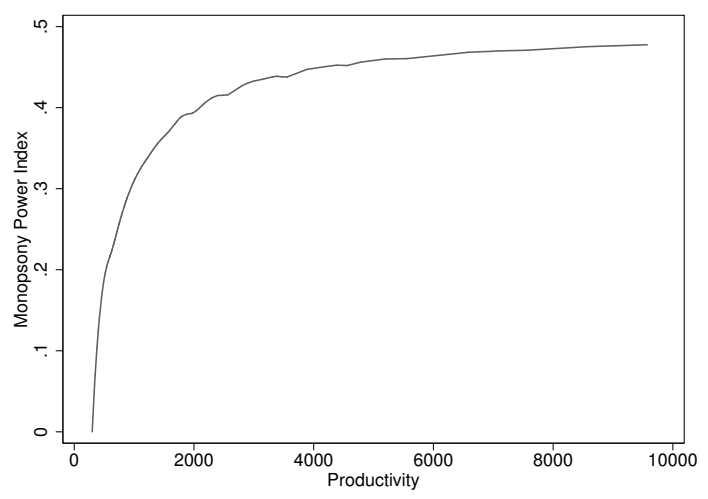

(c) Belo Horizonte

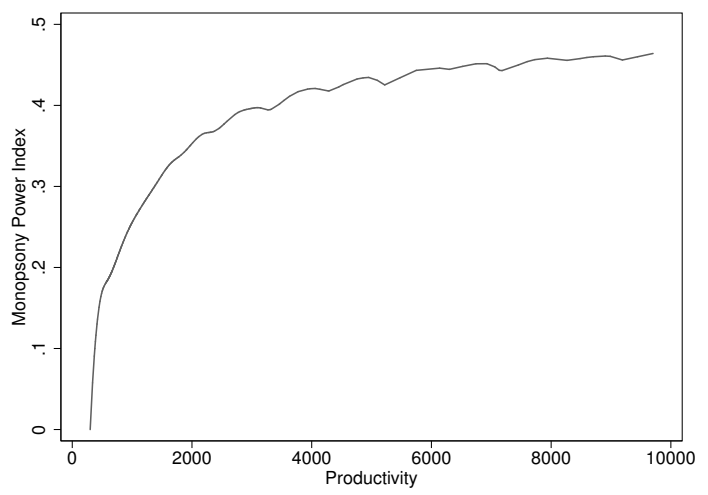

(e) São Paulo

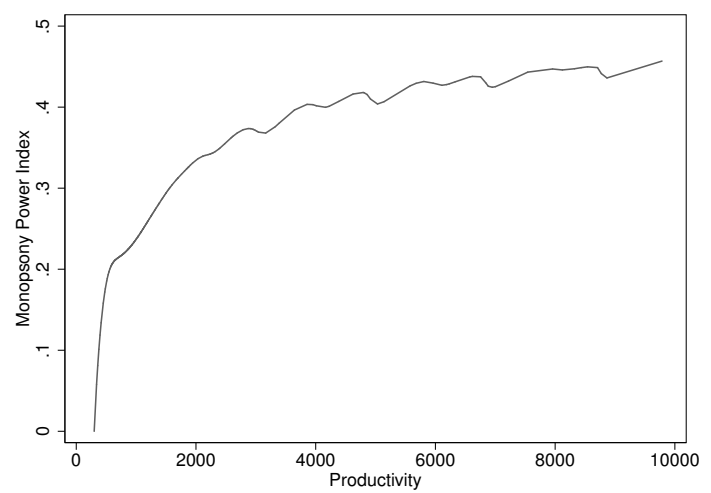

(b) Salvador

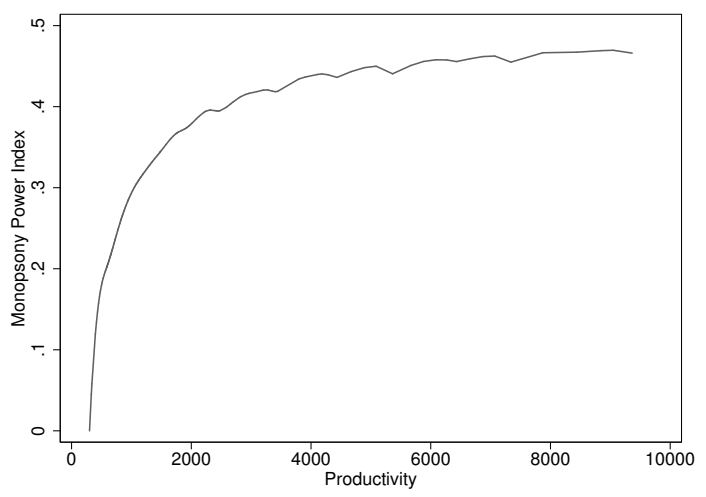

(d) Rio de Janeiro

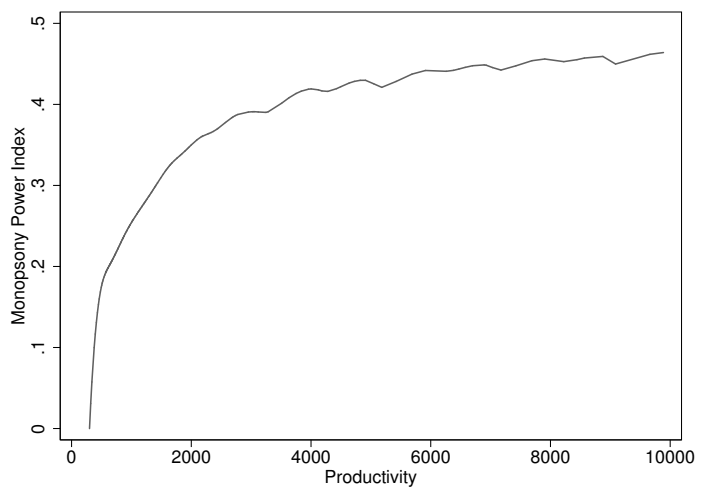

(f) Porto Alegre

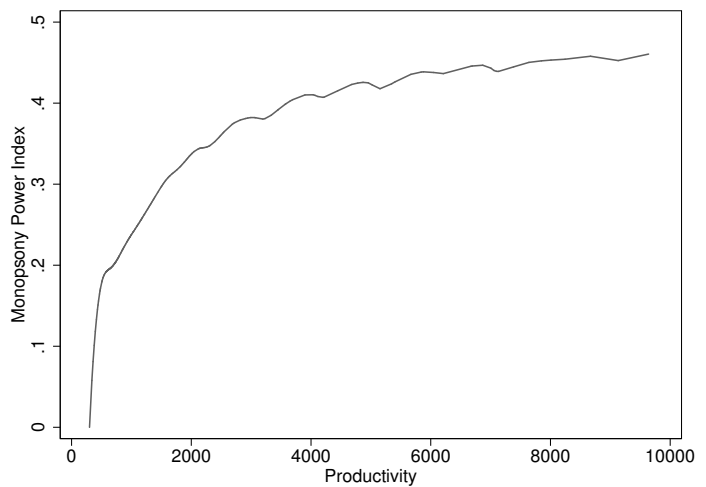


and 30\% in Recife and São Paulo, respectively. This result reveals that employed workers in Recife are in a worse situation than those in São Paulo. This is because, for the same productivity level, workers in Recife receive relatively lower wages. What can be partly explained by the higher level of friction present in the labor market in this region.

So, what does the trio "monopsony power", productivity and wages can explain in terms of regional labor market inequalities? We think that, in a sense, we could interpret our evidence by noting that Figure 5 seems to back up a pattern where Recife and Salvador (both in the Northeastern region), specially between a productivity range of 1,000-3,000, present higher monopsony power due to either existing higher labor market frictions (see Table 7 on page 91) or ceteris paribus the role of unions on these regions, the latter point having some support on papers by Amadeo (1994), Carneiro (1998), and Menezes-Filho, Chahad, Zylberstajn, \& Pazello (2008). Although we offer new initial hints, we think we still lack a complete structural explanation on the regional productivity inequality in Brazil.

\section{CONCLUDING REMARKS}

By considering the presence of search frictions in the labor market, job search theory is able to generate interesting theoretical results, such as involuntary unemployment, monopsony power and wage dispersion. However, although there is already a literature on empirical studies based on models of job search which are well developed internationally, ${ }^{16}$ this literature is almost nonexistent in Brazil. Thus, this study sought to develop an empirical analysis for the Brazilian labor market based on the job search theory and, more importantly, we use the deep estimated structural parameters to shed new light over the important debate about labor regional inequality in Brazil.

To this end, the paper developed a comparison between metropolitan areas that constitute the PME based on a estimated equilibrium job search model with continuous productivity dispersion. Two forms of wage determination are considered: bilateral bargaining and wage posting. We tried to get evidence to determine which way is best suited to the Brazilian labor market, and found favorable evidence to the bilateral bargaining solution. The work follows the paradigm of structural econometrics by incorporating theoretical constraints upon model estimation. The analysis is performed using the nonparametric method developed in Bontemps et al. (2000). From the estimation of frictional parameters and the type of wage determination made, the method allows to recover the productivity distribution (unobserved) associated with the observed wages distribution.

Regarding the results, there are differences in the values of estimated frictional parameters for the regions. The unemployment duration is considerably lower in the metropolitan area of Belo Horizonte, 4.39 months, while for Salvador, the expected duration of a complete episode of unemployment is approximately 11 months. Metropolitan areas like Recife and Salvador have a higher level of search friction, which has direct impact on competition between firms. With respect to the type of wage determination, the determination hypothesis via a bilateral bargaining process seems more appropriate than the assumption of wage posting. In the case of wage posting, we are not able to find the (theoretically expected) strictly increasing relationship between wages and productivity, which is a violation of the theoretical restriction that wage policy function must be increasing in relation to firm's productivity. This condition is satisfied if we assume the case of bilateral bargaining. This result is the same found by Mortensen (2003) to Denmark.

From the estimated productivity values, we calculated the proportion of productivity that remains within the firm, i.e., it is not appropriated in the form of wage by the worker. Comparing the metropoli$\tan$ areas of Recife and São Paulo, one realizes that the latter contains lower levels of monopsony power than the former. For the same level of productivity, a worker in the metropolitan region of São Paulo has a higher wage. This is possibly a result of a higher level of competition between firms in this region caused by a lower level of search friction in the labor market. In terms of public policy, it is evident

\footnotetext{
${ }^{16}$ See Eckstein \& van den Berg (2007).
} 
that the information flow among workers and employers have a key role in the labor market. Thus, employment agencies could possibly reduce the information cost, reducing the inefficiencies generated by search friction in the market. Moreover, more flexible labor laws can reduce the costs associated with changes between jobs by workers decreasing regional disparities on earnings.

Overall, we are able to rationalize Brazilian regional inequalities on unemployment rates and the estimated deep parameters of our model, say, $\lambda_{0}, \lambda_{1}$ and $\delta$. In fact, our results strongly suggest that an important share of regional unemployment rate inequality can be explained by search frictions, more specifically the arrival rate of job offers while employed $\left(\lambda_{1}\right)$. Metropolitan regions in the Northeast have much lower $\lambda_{0}$ and $\lambda_{1}$ vis a vis areas in the South or Southeast regions. This is a new, and much more precise, result worth considering on the regional inequality debate in Brazil.

Also, regional inequality in wages, besides being an outcome of its regional human capital distribution, can be rationalized as inequality of labor market search frictions brought by differences in $\lambda_{1}$. We found a key (indirect) role for search frictions when analysing productivity differences. Since search frictions impact simultaneously on monopsony power as well as on productivity, in order to start to understand regional productivity differences we must deepen our analysis on how these structural parameters are differentiated by regions.

Some extensions of the work become interesting. The analysis can be extended to various demographic groups defined by gender, age, education, etc. Another extension would be a study based on a model that incorporates the presence of formal and informal sectors, which seems to be relevant to the analysis of the Brazilian labor market.

\section{REFERENCES}

Albrecht, J. W., \& Axell, B. (1984). An equilibrium model of search unemployment. Journal of Political Economy, 92(5), 824-40. doi: 10.1086/261260

Amadeo, E. J. (1994). Bargaining power, mark-up power, and wage differentials in Brazil. Cambridge Journal of Economics, 18(3), 313-322. Retrieved from http://cje.oxfordjournals.org/content/18/3/313.short

Araújo, T. P. d., \& Lima, R. A. d. (2010). Aspectos estruturais do mercado de trabalho em contexto recente da economia brasileira: Contraponto Nordeste-Sudeste. In A. Moretto, J. D. Krein, M. Pochmann, \& J. Macambira (Eds.), Economia, desenvolvimento regional e mercado de trabalho do Brasil (pp. 105-138). Fortaleza: Instituto de Desenvolvimento do Trabalho; Banco do Nordeste do Brasil; Centro de Estudos Sindicais e de Economia do Trabalho.

Arbache, J. S. (1999). Do unions always decrease wage dispersion? The case of Brazilian manufacturing. Journal of Labor Research, 20(3), 425-436. doi: 10.1007/s12122-999-1009-7

Azzoni, C. R., \& Servo, L. (2002). Education, cost of living and regional wage inequality in Brazil. Papers in Regional Science, 81(2), 157-175. doi: 10.1111/j.1435-5597.2002.tb01228.x

Barros, R. P. d., Foguel, M. N., \& Ulyssea, G. (Eds.). (2006). Desigualdade de renda no Brasil: Uma análise da queda recente (Vol. 1). Brasília DF: Ipea. Retrieved from http://repositorio.ipea.gov.br/bitstream/11058/3249/1/ Desigualdade\%20de\%20renda\%20no\%20Brasil\%20-\%20v.\%201.pdf

Barros, R. P. d., \& Mendonça, R. S. P. d. (1995, July). Os determinantes da desigualdade no Brasil (Texto para Discussão No. 377). Rio de Janeiro: Instituto de Pesquisa Econômica Aplicada (IPEA). Retrieved from http:// www.ipea.gov.br/portal/index.php?option $=$ com_content\&view $=$ article\&id $=3490$

Behrman, J. R., \& Birdsall, N. (1983). The quality of schooling: Quantity alone is misleading. The American Economic Review, 928-946.

Bontemps, C., Robin, J.-M., \& van den Berg, G. J. (2000). Equilibrium search with continuous productivity dispersion: Theory and nonparametric estimation. International Economic Review, 41(2), 305-358. Retrieved from http://www.jstor.org/stable/2648885

Bunzel, H., Christensen, B. J., Jensen, P., Kiefer, N. M., Korsholm, L., Muus, L., ... Rosholm, M. (2001, January). Specification and estimation of equilibrium search models. Review of Economic Dynamics, 4(1), 90-126. doi: 10.1006/redy.1999.0092 
Burdett, K., \& Mortensen, D. T. (1998). Wage differentials, employer size, and unemployment. International Economic Review, 39(2), 257-273. doi: 10.2307/2527292

Cameron, A. C., \& Trivedi, P. K. (2005). Microeconometrics: Methods and applications. Cambridge University Press.

Carneiro, F. G. (1998). Productivity effects in Brazilian wage determination. World Development, 26(1), 139-153. doi: 10.1016/S0305-750X(97)10013-4

Carvalho, J. R. (2012). Desigualdades salariais entre Nordeste e Sudeste: Explicações "estruturais" através de um modelo de busca por emprego com dados retrospectivos. Revista Econômica do Nordeste, 43(4), 119-140.

Cavalcante, L. R., \& De Negri, F. (2014). Evolução recente dos indicadores de produtividade no Brasil. In F. De Negri \& L. R. Cavalcante (Eds.), Produtividade no Brasil: Desempenho e determinantes (Vol. I, pp. 143-172). Brasília DF: Ipea; ABDI.

Corseuil, C. H., Gonzaga, G., \& Issler, J. V. (1997, Jan). Desemprego regional no Brasil: Uma abordagem empírica (Texto para Discussão No. 475). Instituto de Pesquisa Econômica Aplicada (Ipea). Retrieved from http:// www.ipea.gov.br/portal/index.php?option $=$ com_content\&view $=$ article\&id $=3681$

Diamond, P. A. (1971). A model of price adjustment. Journal of Economic Theory, 3(2), 156-168. doi: 10.1016/00220531(71)90013-5

Duarte, A. J. M., Ferreira, P. C., \& Salvato, M. A. (2004, March). Regional or educational disparities? A counterfactual exercise (Ensaios Econômicos No. 532). Fundação Getulio Vargas (FGV). Retrieved from http://bibliotecadigital.fgv.br/dspace/handle/10438/1013

Eckstein, Z., \& van den Berg, G. J. (2007). Empirical labor search: A survey. Journal of Econometrics, 136(2), 531-564. doi: 10.1016/j.jeconom.2005.11.006

Eckstein, Z., \& Wolpin, K. I. (1990). Estimating a market equilibrium search model from panel data on individuals. Econometrica, 58(4), 783-808. doi: 10.2307/2938350

Feijó, C. A., \& Carvalho, P. G. M. d. (2002). Uma interpretação sobre a evolução da produtividade industrial no Brasil nos anos noventa e as "leis" de Kaldor. Nova Economia, 12(2), 57-78. Retrieved from http:// revistas.face.ufmg.br/index.php/novaeconomia/article/view/401

Freguglia, R. S., \& Menezes-Filho, N. A. (2012). Inter-regional wage differentials with individual heterogeneity: Evidence from Brazil. The Annals of Regional Science, 49(1), 17-34. doi: 10.1007/s00168-010-0432-2

Galeano, E. A. V., \& Wanderley, L. A. (2013a). Produtividade industrial do trabalho e intensidade tecnológica nas regiões do Brasil: Uma análise regional e setorial para o período 1996-2007. Planejamento e Políticas Públicas, 40. Retrieved from http://www.ipea.gov.br/ppp/index.php/PPP/article/view/370

Galeano, E. V., \& Wanderley, L. A. (2013b). Um estudo sobre o comportamento da produtividade industrial do trabalho nas regiões do Brasil no período de 1996 a 2010. Geografares, 15, 139-180. doi: 10.7147/GE015.4839

Kaldor, N. (1970). The case for regional policies. Scottish Journal of Political Economy, 17(3), 337-348. doi: 10.1111/j.1467-9485.1970.tb00712.x

Kiefer, N. M., \& Neumann, G. R. (1993). Wage dispersion with homogeneity: The empirical equilibrium search model. In H. Bunzel, P. Jensen, \& N. Westergåd-Nielsen (Eds.), Panel data and labor market dynamics (pp. 57-74). New York: North-Holland.

Kyyrä, T. (2007). Estimating equilibrium search models from Finnish data. Finnish Economic Papers, 20(2). Retrieved from http://www.taloustieteellinenyhdistys.fi/images/stories/fep/fep22007_kyyra.pdf

Lancaster, T. (1990). The econometric analysis of transition data. Cambridge University Press.

Langoni, C. G. (2005). Distribuição da renda e desenvolvimento econômico do Brasil. FGV Editora.

Menezes-Filho, N. A., Chahad, J. P., Zylberstajn, H., \& Pazello, E. T. (2008). Trade unions and the economic performance of Brazilian establishments. Estudos Econômicos, 38(1), 55-72. doi: 10.1590/S010141612008000100003

Menezes-Filho, N. A., \& Picchetti, P. (2000). Os determinantes da duração do desemprego em São Paulo. Pesquisa e Planejamento Econômico, 30(1). Retrieved from http://ppe.ipea.gov.br/index.php/ppe/article/view/175

Mortensen, D. (2003). Wage dispersion: Why are similar workers paid differently. MIT Press.

Oliveira, C. W. d. A., \& Carneiro, F. G. (2001). Flutuações de longo prazo do emprego no Brasil: Uma análise alternativa de co-integração. Revista Brasileira de Economia, 55(4), 493-512. doi: 10.1590/S0034- 
71402001000400003

Oliveira, C. W. d. A., \& Cruz, B. d. O. (2000, Feb). Desigualdades regionais e elasticidade de longo prazo do emprego nos estados do Nordeste com relação ao emprego nacional (Texto para Discussão No. 704). Brasília, DF: Instituto de Pesquisa Econômica Aplicada (IPEA). Retrieved from http://www.ipea.gov.br/portal/index.php ?option $=$ com_content\&view $=$ article\&id $=4126$

Oliveira, P. F. A. d. (2011). Estimação estrutural de um modelo de busca por emprego com dispersão de produtividade: Uma anáise para o Brasil (thesis). Universidade Federal do Ceará-CAEN, Fortaleza CE.

Penido, M., \& Machado, A. F. (2002). Desemprego: Evidências da duração no Brasil metropolitano (Texto para Discussão No. 176). Belo Horizonte: UFMG/Cedeplar. Retrieved from http://www.cedeplar.ufmg.br/pesquisas/ td/TD\%20176.pdf

Queiroz, B. L., \& Golgher, A. B. (2008). Human capital differentials across municipalities and states in Brazil. Population Review, 47(2). doi: 10.1353/prv.0.0008

Reis, J. G. A., \& Barros, R. P. d. (1990). Desigualdade salarial e distribuição de educação: A evolução das diferenças regionais no Brasil. Pesquisa e Planejamento Econômico, 20(3), 415-478.

Rogerson, R., Shimer, R., \& Wright, R. (2005, December). Search-theoretic models of the labor market. Journal of Economic Literature, 43, 959-988. doi: 10.1257/002205105775362014

Savedoff, W. D. (1990). Os diferenciais regionais de salários no Brasil: Segmentação versus dinamismo da demanda. Pesquisa e Planejamento Econômico, 20(3), 521-556.

Savedoff, W. D. (1995). Wages, labour and regional development in Brazil. Avebury.

Schettini, D., \& Azzoni, C. R. (2013). Recent productivity growth and regional inequality in Brazil (Texto para Discussão No. 10-2013). São Paulo: USP/Nereus. Retrieved from http://www.usp.br/nereus/?txtdiscussao= recent-productivity-growth-and-regional-inequality-in-brazil

Shimer, R. (2006). On-the-job search and strategic bargaining. European Economic Review, 50(4), 811-830. doi: 10.1016/j.euroecorev.2006.01.008

Sulis, G. (2008). Wage dispersion and equilibrium search models: Some evidence from Italy. LABOUR, 22(4), 593-627. doi: 10.1111/j.1467-9914.2008.00426.x

van den Berg, G. J., \& Ridder, G. (1998). An empirical equilibrium search model of the labor market. Econometrica, 66(5), 1183-1222. doi: 10.2307/2999634

van den Berg, G. J., \& van Vuuren, A. (2003, July). The effect of search frictions on wages (Discussion Paper No. 3979). London: Centre for Economic Policy Research (CEPR). 